\title{
Lipolysis and aroma occurrence in Erzincan Tulum cheese, which is produced by adding probiotic bacteria and ripened in various packages
}

\author{
Gökhan AKARCA ${ }^{1 *}$
}

\begin{abstract}
This study aimed to investigate the physicochemical, volatile components and fatty acids profile of Erzincan Tulum cheeses, produced using different probiotic bacteria and packaging materials, during the ripening period. Erzincan Tulum Cheese, which is the most popular and highly consumed cheese species in Turkey. Tulum cheese were ripened in skin bag (Tulum), appendix and small intestine. The ripening time influenced the $\mathrm{pH}$, ripening index, FFA, CLA and volatile components of samples. The short chain FFA varied between $16.36 \%$ and $21.76 \%$, while medium-chain FFA varied between $37.44 \%$ and $39.43 \%$, and long chain FFA between $32.61 \%$ and $37.48 \%$ during the ripening periods. The highest CLA value was determined as $0.82 \%$ for the samples produced with Lactobacillus acidophilus bacteria and stuffed into the small intestine. All volatile components were increased, moreover the highest content of ester, ketones, aldehydes, terpenes, alcohols were 3-methyl-1-butanol acetate, 2-Pentanone, hexanal, a-Pinene, 3-methyl-1-butanol. All sensory evaluation scores decreased during storage. According to the general acceptance values, the most favoured sample was TCMA with 7.34, whereas the least favoured was TCBS with 4.82 score $(\mathrm{P}<0.05)$.
\end{abstract}

Keywords: Tulum cheese; probiotic; fatty acids; CLA; volatile compounds; hexanal.

Practical Application: The effects of probiotic culture on Tulum cheese quality.

\section{Introduction}

Cheese is the most produced dairy product in Turkey, which is one of the greatest producers of milk and dairy production in its region (Yilmaz et al., 2005). Although more than 130 types of cheese are produced in the country today, three kinds (White, kashar, and Tulum cheese) come to the forefront. Erzincan Tulum cheese is the most admired and preferred types of cheese among the Tulum cheeses that are ripened in different ways depending on the production method (brine or dry type) (Çakır \& Cakmakci, 2018). Types of cheese vary depending on changes in storing time and conditions during the ripening of the cheese, and very complex chemical and biochemical reactions such as glycolysis, proteolysis, and lipolysis Lipolysis has a great importance in cheesemaking technology. Short and medium chain fatty acids profile analysis is generally used in the chemical characterization of the ripening level in cheese (McSweeney \& Sousa, 2000). Free fatty acids (FFA) are produced as a result of degradation of fat in cheese via lipolysis. These different FFA characterizations contribute differently to flavor in types of cheese (Molimard \& Spinnler, 1996). The impact of natural lipase, which is found in milk, on lipolysis varies depending on heat treatments applied to milk.

Probiotics are defined as living microorganisms, which have positive effects on the health of the host when consumed regularly and sufficiently. Today, numerous research studies are conducted on probiotic addition to various foods. Milk and dairy products are the food kinds, in which probiotic microorganisms are mostly added (Stanton et al., 1998; Hill et al.,
2014). Since fermented foods such as dairy products and yogurt have shorter shelf lives compared to cheese types, they cannot provide long-term storage areas for probiotic microorganisms (Mukdsi et al., 2013). On the other hand, since the cheese has a stiffer structure and higher $\mathrm{pH}$ and fat content, it can protect probiotic microorganisms more efficiently and for longer periods compared to other fermented dairy products (Alves et al., 2013; Mukdsi et al., 2013). It has been reported that probiotic cheese types including Prato cheese, Cheddar cheese, Minas cheese, Pategras cheese and Turkish white cheese have been produced (Lavasani \& Ehsani, 2012; Kinik et al., 2017; Murtaza et al., 2017; Almeida et al., 2018a; Silva et al., 2018a, b).

Cheese is one of the most suitable dairy products for supplement probiotic bacteria in the gastrointestinal tract compared with yoghurt and kefir. Due to higher $\mathrm{pH}$, it composes a cushion against the high acidic condition in the gastrointestinal tract, and in this manner makes a progressively great condition for probiotic survival along the gastric, because of higher $\mathrm{pH}$. Also, cheese may offer supplemental conservation to probiotic microorganisms in the stomach with hard matrix and comparatively high fat content (Cruz et al., 2009; Thomas, 2016; Kinik et al., 2017; Silva et al., 2018b).

Packaging materials and storage conditions are important factors for the quality of products containing probiotic microorganisms (Champagne et al., 2005; Cruz et al., 2007). During storage, the oxygen level in the package of the product should be as low as 
possible. Otherwise it may affect the toxicity of the microorganism and may even lead to death. Furthermore, as a result, loss of functionality in the product occurs. Exposure to dissolved oxygen during the process and storage for Bifidobacterium spp. and Lactobacillus acidophilus is highly damaging. Although depending on the strain used, Bifidobacterium spp. is more sensitive to oxygen than Lactobacillus acidophilus. (Talwalkar \& Kallasapathy, 2003; Cruz et al., 2007).

This is a serious problem, as almost all probiotic dairy products sold on the market are found in plastic packages with high oxygen permeability. Studies on the use of suitable packaging for probiotic foods are generally limited to active packages (oxygen absorbers) and plastic films with high oxygen barrier properties. More detailed studies are needed to ensure safe and high conservation of probiotic microorganisms for longer periods of time. More detailed studies are needed to ensure the preservation of probiotic microorganisms for longer periods of time and in high numbers (Cruz et al., 2007; Champagne et al., 2018).

This study aimed to investigate the physicochemical, volatile components and fatty acids profile of Erzincan tulum cheeses, produced using different probiotic bacteria and packaging materials, during the ripening period.

\section{Materials and methods}

\subsection{Material}

Sheep milk that is used in the making of Tulum cheeses was obtained from milk producers within Erzincan province from the Ak Karaman breed sheep ( $\mathrm{pH} 7.01$, titratable acidity $0.19 \%$, density $1.05 \mathrm{~g} / \mathrm{mL}$, dry matter $20.12 \%$, protein $6.04 \%$, fat $8.75 \%$ ).

\subsection{Cheese making}

The milk that was clarified by passing through clarificators was cooled to $33{ }^{\circ} \mathrm{C}$ after being processed to heat treatment for 15 seconds at $75^{\circ} \mathrm{C}$. Milk was coagulated with calf rennet (Mayasan Inc., Istanbul, Turkey) which coagulation strength had 1:16000 MCU mL $\mathrm{mL}^{-1}$ at $33^{\circ} \mathrm{C}$ for 90 minutes. Curd that occurred at the end of this period was disintegrated to $1 \mathrm{~cm}^{3}$ sized particles and whey was removed. After that, the curd was stored for 6-7 days at $22-24^{\circ} \mathrm{C}$ by filling into cotton sacks. By this means, it was provided that the remaining whey was removed. At the end of the period, curd in the sacks was disintegrated into particles that have the size of a chickpea and were mixed homogeneously after adding 3\% Erzincan rock salt. After this process, the curd was divided into three equal parts and Lactobacillus acidophilus (Pro Lafti L10) and Bifidobacterium animalis spp. lactis (Pro Lafti B-94) bacteria ( $\geq 7$ Log CFU/g) were added in it. After ensuring that a homogeneous mixture was provided, the curds were stuffed into cotton sacks again and by this way, the initial ripening process was conducted $\left(22^{\circ} \mathrm{C}, 3\right.$ days). The cheeses that were taken out from the sacks were disintegrated again, were stuffed into Tulum, small intestine, and appendix, and then they were subjected to ripening process at storehouses at $1{ }^{\circ} \mathrm{C}$ and $75-80 \%$ relative humidity for 90 days.

\section{$2.3 p H$}

The $\mathrm{pH}$ was measured in a homogenate prepared by blending $10 \mathrm{~g}$ of a sample with $15 \mathrm{~mL}$ of distilled water for 30 seconds. $\mathrm{pH}$ values were obtained with glass electrode attached to a Hanna pH meter (Model 2215, Hanna Instruments, USA) (Association of Official Analytical Chemists, 2012).

\subsection{Ripening index}

Index of ripening of the Tulum cheese samples was determined by Kurt et al. (2015) method, by using the Kjeldahl method with the rate of the amount of protein dissolved in water to the total amount of protein.

\subsection{Fatty acid analysis}

The Tulum cheese samples were homogenized primarily with chloroform: methanol (Merck) $(2: 1 \mathrm{v} / \mathrm{v})$ mixture (Ultra-Turrax ${ }^{\circledR}$, $5 \mathrm{~min}$.). Esterification processes of samples were carried out by using n-heptane and methanolic KOH. Fatty acids analysis was carried out by gas chromatography (GC Agilent $6890 \mathrm{~N}$, flame ionization detector [FID], controlled oven: $65-250^{\circ} \mathrm{C}, 4^{\circ} \mathrm{C} / \mathrm{min}$ and HP-88 capillary-column [100 $\mathrm{m}, 0.25 \mathrm{~mm}$ id ve $0.2 \mathrm{um}]$ ) (Zengin et al., 2011).

\subsection{Volatile compounds}

Aroma analyses of the Tulum cheeses were conducted by solid-phase microextraction method (SPME, using a fiber $57348-\mathrm{U}$, coated with the sorbent material, divinyl benzene/carboxen/polydimethylsiloxane (DBCP), Supelco Inc., Bellefonte, PA, USA) using gas chromatography (GC) (Clarus 600, Pelkin Elmer Inc., Massachusetts, USA) equipped with a flame ionization detector. A BP-20 wax capillary column (SGE International Pty. Ltd., Victoria, Australia; $30 \mathrm{~m} \times 0.25 \mathrm{~mm}$ i.d.x $0.25 \mu \mathrm{m}$ film thickness) as Akpınar et al. (2017) stated.

\subsection{Sensory analysis}

In the sensory assessment of the cheese, samples were analysed by a 18 (two times the number of samples) trained member panel of the department of food engineering. The panellists were selected on the basis of their interest and experience in sensory analysis of Tulum cheeses. The score cards were used for sensory evaluation. The hedonic scale used a 9-point scale, where 1-3 was not acceptable, $4-5$ was fairly acceptable, 6-7 was well acceptable, 8-9 was very good for apparance, taste and odour, texture, flavor and general appreciation (Ercan et al., 2011; Tomar, 2018).

\subsection{Statistical analysis}

The research design was completely randomized having a factorial structure $(3 \times 3 \times 4)$. The factors were probiotic (L. acidophilus, B. animalis spp. lactis, and L. acidophilus + B. animalis spp. lactis), packaging (Skin bag, appendix, and intestine), and storage time (2, 30, 60 and 90 day). Three-way ANOVA was applied to data using procedure of the SPSS statistical package program (SPSS Inc., Chicago, IL) to do this analysis. 


\section{Results and discussion}

The ripening time high significantly $(\mathrm{P}<0.0001)$ influenced the $\mathrm{pH}$ value of samples. In all of the Tulum cheese samples, the $\mathrm{pH}$ values decreased during the ripening period $(\mathrm{P}<0.05)$. In the beginning, the lowest $\mathrm{pH}$ value was detected as 4.96 in the samples that were produced by adding the mixture of L. acidophilus and B. animalis spp. lactis and stuffed into Tulum, whereas at the end of the 90-day ripening period the value was detected as 4.54 in the samples that were produced by adding the $B$. animalis spp. lactis and stuffed into the small intestine and appendix (Table 1). The results obtained are similar to the values detected by Yilmaz et al. (2005), Sengul et al. (2014) and Sert et al. (2014). In addition, Almeida et al. (2018b) determined increase in acidity in all the probiotic added Mascarpone-type cheese samples. In addition to, Celik \& Tarakci (2017) stated that the type of the starter cultures decreased the $\mathrm{pH}$ values of Tulum cheese samples during the ripening. Results indicate that the regarding decrease in $\mathrm{pH}$ values in all the samples during storage period was due to the lactic acid produced by the activities of starter and non-starter bacteria found in the cheese which could ferment lactose (Tomar et al., 2018).

The ripening time and Ripening Time $\times$ Packaging interactions were influenced the ripening index of cheese samples high significantly $(\mathrm{P}<0.0001)$. The ripening index value in all of the Tulum cheese samples increased during the storage period $(\mathrm{P}<0.05)$. At the beginning of the storage, the lowest value was detected as 6.53 in the samples that were produced by adding the mixture of $L$. acidophilus and B. animalis spp. lactis and stuffed into the appendix, whereas at the end of the storage the highest value was detected as 25.76 in the samples which were produced with the same mixture and stuffed into the small intestine (Table 1).

In cheese, the ripening index ratio between $33-66 \%$ is under the category of full-ripened cheese, lower than $33 \%$ is under the category of light-ripened cheese (Kurt et al., 2015). Accordingly, the Tulum cheese samples are under the category of less ripened cheese.
Tarakci \& Durmuş (2016) determined that the ripening index values of the cheeses ripened in skin and plastic materials were higher than those ripened in cloth, animal stomach and pot materials. Yasar (2007) and Gun (2012) stated that the ripening index increased for the cheeses that were stored time. The ripening index value in the cheese samples in which the mixture of L. acidophilus and B. animalis spp. lactis were added was determined higher than the other cheese samples. The rennet, plasmin, non-starter lactic acid bacteria, yeast, molds, and the enzymes synthesized by psychrophilic bacteria have an effect on the proteolysis in the cheese (Dagdemir, 2006).

The ripening time high significantly $(\mathrm{P}<0.0001)$ influenced all faty acids of samples, ripening time $\times$ packaging interactions were influenced the butanoic acid (C 4:0) of cheese samples significantly $(\mathrm{P}<0.05)$. During the 90 -day ripening period in the Tulum cheese samples the palmitic acid (C 16:0) with 26.98 was the most abundant fatty acid $(\mathrm{P}<0.05)$, which was followed by the oleic acid $(\mathrm{C} \mathrm{18:1)}$ with $25.38(\mathrm{P}<0.05)$ and the myristic (C 14:0) acids with $13.35(\mathrm{P}<0.05)$ (Table 2$)$.

These detected values are similar to the results obtained in the studies of Yilmaz et al. (2005), Gun (2012), Sert et al. (2014) and. Sengul et al. (2014). Likewise, the palmitic acid was detected as the highest fatty acid with an average value of 26.11 in the cheeses that were produced with the addition of B. animalis spp. lactis probiotic bacteria and with an average value of 26.08 in the cheeses which were stuffed into Tulum package. On the other hand, the butyric acid with a value of 1.87 , the linoleic acid with a value of 2.09, the capric acid with a value of 2.14, and the caproic acids with a value of 2.49 were the least detected fatty acids in the Tulum cheese samples during the storage period (Table 2).

The high levels of palmitic and oleic acids can be explained, because the lipases of the lactic acid bacteria released them in a preferentially after the short chain fatty acids (Kamaly et al.,1990).

The ripening time high significantly $(\mathrm{P}<0.0001)$ influenced conjugated linoelic acid (CLA). The CLA values in Tulum cheeses that were produced by the addition of three different probiotic bacteria and ripened by filling into three different

Table 1. The $\mathrm{pH}$ value and ripening index varience in the Tulum cheese samples based on storage.

\begin{tabular}{|c|c|c|c|c|c|c|c|c|}
\hline \multirow{3}{*}{ Samples } & \multicolumn{4}{|c|}{$\mathrm{pH}$} & \multicolumn{4}{|c|}{ Ripening Index } \\
\hline & \multicolumn{4}{|c|}{ Ripening Time (Days) } & \multicolumn{4}{|c|}{ Ripening Time (Days) } \\
\hline & 2 & 30 & 60 & 90 & 2 & 30 & 60 & 90 \\
\hline TCLS & $5.07^{a}$ & $4.89^{\mathrm{b}}$ & $4.78^{c}$ & $4.63^{d}$ & $7.79^{d}$ & $8.88^{c}$ & $12.82^{b}$ & $20.46^{\mathrm{a}}$ \\
\hline TCLI & $5.00^{\mathrm{a}}$ & $4.85^{\mathrm{b}}$ & $4.76^{c}$ & $4.65^{\mathrm{d}}$ & $8.10^{\mathrm{d}}$ & $9.33^{c}$ & $12.97^{b}$ & $20.42^{\mathrm{a}}$ \\
\hline TCLA & $5.04^{\mathrm{a}}$ & $4.97^{\mathrm{ab}}$ & $4.82^{\mathrm{b}}$ & $4.74^{c}$ & $7.40^{\mathrm{d}}$ & $9.70^{c}$ & $12.89^{b}$ & $20.18^{\mathrm{a}}$ \\
\hline TCBS & $5.08^{\mathrm{a}}$ & $4.91^{\mathrm{b}}$ & $4.80^{c}$ & $4.64^{\mathrm{d}}$ & $8.10^{\mathrm{d}}$ & $9.17^{c}$ & $13.75^{b}$ & $21.01^{\mathrm{a}}$ \\
\hline TCBI & $5.03^{\mathrm{a}}$ & $4.92^{\mathrm{b}}$ & $4.77^{c}$ & $4.54^{\mathrm{d}}$ & $7.89^{\mathrm{d}}$ & $9.19^{c}$ & $13.23^{b}$ & $20.60^{\mathrm{a}}$ \\
\hline TCBA & $5.06^{\mathrm{a}}$ & $4.92^{\mathrm{b}}$ & $4.80^{c}$ & $4.54^{\mathrm{d}}$ & $7.35^{\mathrm{d}}$ & $9.46^{c}$ & $13.85^{b}$ & $21.54^{\mathrm{a}}$ \\
\hline TCMS & $4.96^{\mathrm{a}}$ & $4.88^{\mathrm{b}}$ & $4.78^{c}$ & $4.60^{\mathrm{d}}$ & $7.42^{\mathrm{d}}$ & $10.98^{c}$ & $14.55^{\mathrm{b}}$ & $22.27^{\mathrm{a}}$ \\
\hline TCMI & $5.08^{\mathrm{a}}$ & $4.97^{\mathrm{b}}$ & $4.79^{b c}$ & $4.71^{\mathrm{c}}$ & $7.75^{\mathrm{d}}$ & $11.98^{c}$ & $17.35^{\mathrm{b}}$ & $25.76^{\mathrm{a}}$ \\
\hline TCMA & $5.07^{\mathrm{a}}$ & $4.83^{\mathrm{b}}$ & $4.80^{\mathrm{bc}}$ & $4.76^{\mathrm{c}}$ & $6.53^{\mathrm{d}}$ & $10.71^{\mathrm{c}}$ & $13.02^{\mathrm{b}}$ & $23.96^{\mathrm{a}}$ \\
\hline
\end{tabular}

TCLS = Tulum cheese with Lactobacillus acidophilus stuffed into skin bag; TCLI = Tulum cheese with Lactobacillus acidophilus stuffed into small intestine; TCLA = Tulum cheese with Lactobacillus acidophilus stuffed into appendix; TCBS = Tulum cheese with Bifidobacterium animalis spp. lactis stuffed into skin bag; TCBI = Tulum cheese with Bifidobacterium animalis spp. lactis stuffed into small intestine; TCBA = Tulum cheese with Bifidobacterium animalis spp. lactis stuffed into appendix; TCMS = Tulum cheese with mix probiotic bacteria stuffed into skin bag; TCMI = Tulum cheese with mix probiotic bacteria stuffed into small intestine; TCMA = Tulum cheese with mix probiotic bacteria stuffed into appendix. a-d $(\rightarrow)$ The difference between the averages carrying the same letters is not statistically significant $(P>0.05)$. 
Table 2. Fatty acid distribution of Tulum cheese samples (\%).*

\begin{tabular}{|c|c|c|c|c|c|c|c|c|c|c|c|c|c|c|c|c|c|}
\hline Samples & $\begin{array}{c}\mathrm{RT} \\
\text { (Day) }\end{array}$ & C4:0 & C6:0 & C8:0 & C10:0 & $12: 0$ & C14:0 & $\mathrm{C} 16: 0$ & C18:0 & C18:1 & C18:2 & CLA & SFA & USFA & SCFA & MCFA & LCFA \\
\hline \multirow{2}{*}{ TCLS } & 30 & $1.53^{\text {cd }}$ & $1.85^{\mathrm{d}}$ & $2.04^{\mathrm{c}}$ & $6.95^{\mathrm{e}}$ & $4.22^{c}$ & $12.21^{\mathrm{bc}}$ & $26.96^{\mathrm{a}}$ & $10.92^{\mathrm{a}}$ & $23.58^{c}$ & $2.13^{\mathrm{ab}}$ & $0.46^{\mathrm{ef}}$ & 55.76 & 36.63 & 16.59 & 39.17 & 36.63 \\
\hline & 90 & $1.71^{\mathrm{c}}$ & $1.89^{\mathrm{d}}$ & $2.21^{\mathrm{c}}$ & $7.49^{\mathrm{d}}$ & $4.28^{\mathrm{c}}$ & $11.94^{c}$ & $25.53^{\mathrm{b}}$ & $9.98^{\mathrm{b}}$ & $25.28^{\mathrm{a}}$ & $2.18^{\mathrm{ab}}$ & $0.67^{c}$ & 55.05 & 37.44 & 17.58 & 37.47 & 37.44 \\
\hline \multirow[t]{3}{*}{ TCLI } & 2 & $1.67^{\mathrm{cd}}$ & $2.24^{\mathrm{c}}$ & $2.54^{\mathrm{b}}$ & $8.52^{\mathrm{bc}}$ & $5.29^{\mathrm{a}}$ & $13.16^{\mathrm{a}}$ & $25.26^{\mathrm{b}}$ & $9.93^{b}$ & $23.20^{\mathrm{d}}$ & $1.90^{\mathrm{d}}$ & $0.48^{\mathrm{ef}}$ & 58.68 & 35.03 & 20.26 & 38.42 & 35.03 \\
\hline & 30 & $1.59^{\mathrm{cd}}$ & $1.78^{\mathrm{d}}$ & $2.02^{c}$ & $7.04^{\mathrm{e}}$ & $4.27^{c}$ & $12.28^{\mathrm{b}}$ & $26.62^{\mathrm{a}}$ & $11.12^{\mathrm{a}}$ & $23.79^{b c}$ & $2.17^{\mathrm{ab}}$ & $0.56^{\mathrm{de}}$ & 55.6 & 37.08 & 16.7 & 38.9 & 37.08 \\
\hline & 90 & $1.65^{\mathrm{cd}}$ & $1.89^{\mathrm{d}}$ & $2.09^{c}$ & $7.44^{\mathrm{d}}$ & $4.27^{c}$ & $11.99^{c}$ & $25.45^{\mathrm{b}}$ & $9.94^{\mathrm{b}}$ & $25.19^{\mathrm{a}}$ & $2.09^{\mathrm{abc}}$ & $0.82^{\mathrm{a}}$ & 54.78 & 37.22 & 17.34 & 37.44 & 37.22 \\
\hline \multirow[t]{4}{*}{ TCLA } & 2 & $1.48^{\mathrm{d}}$ & $2.14^{\mathrm{c}}$ & $2.47^{\mathrm{b}}$ & $8.36^{c}$ & $5.11^{\mathrm{b}}$ & $13.22^{\mathrm{a}}$ & $25.15^{\mathrm{b}}$ & $10.14^{\mathrm{b}}$ & $23.13^{d}$ & $1.94^{\mathrm{cd}}$ & $0.46^{\mathrm{ef}}$ & 57.93 & 35.21 & 19.56 & 38.37 & 35.21 \\
\hline & 30 & $1.48^{\mathrm{d}}$ & $1.80^{\mathrm{d}}$ & $2.09^{c}$ & $7.06^{\mathrm{e}}$ & $4.36^{c}$ & $12.35^{\mathrm{b}}$ & $26.71^{\mathrm{a}}$ & $11.11^{\mathrm{a}}$ & $23.97^{b}$ & $2.11^{\mathrm{abc}}$ & $0.50^{\mathrm{e}}$ & 55.85 & 37.19 & 16.79 & 39.06 & 37.19 \\
\hline & 60 & $2.70^{\mathrm{a}}$ & $2.75^{\mathrm{a}}$ & $3.20^{\mathrm{a}}$ & $8.80^{\mathrm{a}}$ & $4.31^{\mathrm{c}}$ & $11.04^{\mathrm{d}}$ & $26.90^{\mathrm{a}}$ & $10.81^{\mathrm{a}}$ & $19.98^{\mathrm{e}}$ & $2.12^{\mathrm{abc}}$ & $0.62^{\mathrm{cd}}$ & 59.7 & 32.91 & 21.76 & 37.94 & 32.91 \\
\hline & 90 & $1.96^{\mathrm{b}}$ & $1.83^{\mathrm{d}}$ & $2.18^{c}$ & $7.55^{\mathrm{d}}$ & $4.18^{c}$ & $12.00^{c}$ & $25.47^{\mathrm{b}}$ & $10.01^{\mathrm{b}}$ & $25.28^{\mathrm{a}}$ & $2.26^{\mathrm{a}}$ & $0.77^{\mathrm{ab}}$ & 55.17 & 37.55 & 17.7 & 37.47 & 37.55 \\
\hline TCBS & 2 & $1.64^{\mathrm{bc}}$ & $2.14^{\mathrm{bc}}$ & $2.57^{\mathrm{b}}$ & $8.42^{\mathrm{cd}}$ & $5.10^{\mathrm{a}}$ & $13.13^{\mathrm{a}}$ & $25.05^{\mathrm{d}}$ & $9.90^{\mathrm{b}}$ & $23.05^{\mathrm{d}}$ & $1.84^{\mathrm{a}}$ & $0.42^{\mathrm{f}}$ & 58.05 & 34.79 & 19.87 & 38.18 & 34.79 \\
\hline \multirow[t]{4}{*}{ TCBI } & 2 & $1.60^{\mathrm{bc}}$ & $2.29^{\mathrm{b}}$ & $2.55^{\mathrm{b}}$ & $8.47^{c}$ & $5.11^{\mathrm{a}}$ & $13.19^{\mathrm{a}}$ & $25.16^{\mathrm{cd}}$ & $9.77^{\mathrm{b}}$ & $23.00^{\mathrm{d}}$ & $2.05^{\mathrm{bc}}$ & $0.51^{\mathrm{e}}$ & 58.37 & 34.82 & 20.02 & 38.35 & 34.82 \\
\hline & 30 & $1.50^{c}$ & $1.67^{\mathrm{e}}$ & $2.06^{\mathrm{cd}}$ & $7.02^{\mathrm{f}}$ & $4.18^{\mathrm{de}}$ & $12.29^{\mathrm{b}}$ & $26.90^{\mathrm{a}}$ & $10.75^{\mathrm{a}}$ & $23.57^{c}$ & $2.21^{\mathrm{a}}$ & $0.58^{\mathrm{d}}$ & 55.62 & 36.53 & 16.43 & 39.19 & 36.53 \\
\hline & 60 & $2.62^{\mathrm{a}}$ & $2.84^{\mathrm{a}}$ & $3.14^{\mathrm{a}}$ & $8.90^{\mathrm{ab}}$ & $4.13^{\mathrm{e}}$ & $11.02^{\mathrm{d}}$ & $26.95^{\mathrm{a}}$ & $10.75^{\mathrm{a}}$ & $19.82^{\mathrm{e}}$ & $2.04^{\mathrm{ab}}$ & $0.66^{c}$ & 59.6 & 32.61 & 21.63 & 37.97 & 32.61 \\
\hline & 90 & $1.85^{\mathrm{b}}$ & $1.83^{\mathrm{de}}$ & $2.12^{\mathrm{cd}}$ & $7.43^{\mathrm{e}}$ & $4.33^{b c}$ & $12.04^{c}$ & $25.45^{\mathrm{bc}}$ & $10.02^{\mathrm{b}}$ & $25.20^{\mathrm{a}}$ & $2.16^{\mathrm{a}}$ & $0.73^{\mathrm{b}}$ & 55.05 & 37.38 & 17.56 & 37.49 & 37.38 \\
\hline \multirow[t]{4}{*}{ TCBA } & 2 & $1.42^{\mathrm{c}}$ & $2.17^{\mathrm{bc}}$ & $2.58^{\mathrm{b}}$ & $8.34^{\mathrm{d}}$ & $5.16^{\mathrm{a}}$ & $13.23^{\mathrm{a}}$ & $25.22^{\mathrm{bcd}}$ & $9.98^{\mathrm{b}}$ & $23.09^{d}$ & $1.98^{\mathrm{bc}}$ & $0.50^{\text {de }}$ & 58.12 & 35.05 & 19.67 & 38.45 & 35.05 \\
\hline & 30 & $1.62^{\mathrm{bc}}$ & $1.86^{\mathrm{de}}$ & $2.04^{\mathrm{d}}$ & $6.94^{\mathrm{f}}$ & $4.40^{\mathrm{b}}$ & $12.45^{\mathrm{b}}$ & $26.98^{\mathrm{a}}$ & $10.93^{\mathrm{a}}$ & $23.94^{\mathrm{b}}$ & $2.11^{\mathrm{ab}}$ & $0.56^{\mathrm{de}}$ & 56.29 & 36.98 & 16.86 & 39.43 & 36.98 \\
\hline & 60 & $2.60^{\mathrm{a}}$ & $2.79^{\mathrm{b}}$ & $3.20^{\mathrm{a}}$ & $8.79^{\mathrm{b}}$ & $4.31^{\mathrm{bc}}$ & $10.99^{\mathrm{d}}$ & $26.87^{a}$ & $10.67^{\mathrm{a}}$ & $19.96^{\mathrm{e}}$ & $2.14^{\mathrm{ab}}$ & $0.62^{\mathrm{cd}}$ & 59.55 & 32.77 & 21.69 & 37.86 & 32.77 \\
\hline & 90 & $1.83^{\mathrm{b}}$ & $1.96^{\mathrm{cd}}$ & $2.23^{\mathrm{c}}$ & $7.48^{\mathrm{e}}$ & $4.17^{\mathrm{de}}$ & $12.03^{c}$ & $25.58^{\mathrm{b}}$ & $9.95^{\mathrm{b}}$ & $25.32^{\mathrm{a}}$ & $2.21^{\mathrm{a}}$ & $0.76^{\mathrm{ab}}$ & 55.28 & 37.48 & 17.67 & 37.61 & 37.48 \\
\hline \multirow[t]{3}{*}{ TCMS } & 2 & $1.77^{\mathrm{b}}$ & $2.28^{\mathrm{b}}$ & $2.63^{\mathrm{cd}}$ & $8.52^{\mathrm{cd}}$ & $5.33^{\mathrm{a}}$ & $10.33^{\mathrm{d}}$ & $25.37^{\mathrm{b}}$ & $10.02^{\mathrm{d}}$ & $23.06^{\mathrm{ab}}$ & $1.87^{c}$ & $0.38^{\mathrm{g}}$ & 56.23 & 34.95 & 20.53 & 35.7 & 34.95 \\
\hline & 30 & $1.49^{c}$ & $1.78^{\mathrm{d}}$ & $2.03^{\mathrm{d}}$ & $6.97^{\mathrm{f}}$ & $4.34^{\mathrm{b}}$ & $12.31^{\mathrm{a}}$ & $26.75^{\mathrm{a}}$ & $11.14^{\mathrm{a}}$ & $23.94^{\mathrm{a}}$ & $2.21^{\mathrm{a}}$ & $0.47^{\mathrm{ef}}$ & 55.67 & 37.29 & 16.61 & 39.06 & 37.29 \\
\hline & 60 & $2.67^{\mathrm{a}}$ & $2.66^{\mathrm{a}}$ & $3.20^{\mathrm{a}}$ & $8.73^{\mathrm{ab}}$ & $4.27^{\mathrm{b}}$ & $11.02^{c}$ & $26.62^{\mathrm{a}}$ & $10.82^{\mathrm{ab}}$ & $19.95^{c}$ & $2.05^{\mathrm{abc}}$ & $0.58^{\mathrm{d}}$ & 59.17 & 32.82 & 21.53 & 37.64 & 32.82 \\
\hline \multirow{2}{*}{ TCMA } & 60 & $2.59^{\mathrm{a}}$ & $2.65^{\mathrm{a}}$ & $3.32^{\mathrm{a}}$ & $8.72^{\mathrm{ab}}$ & $4.33^{\mathrm{b}}$ & $10.95^{\mathrm{a}}$ & $26.69^{\mathrm{a}}$ & $10.65^{b c}$ & $19.60^{c}$ & $2.05^{\mathrm{abc}}$ & $0.60^{\mathrm{d}}$ & 59.25 & 32.3 & 21.61 & 37.64 & 32.30 \\
\hline & 90 & $1.82^{\mathrm{bc}}$ & $1.85^{\mathrm{d}}$ & $2.11^{\mathrm{d}}$ & $7.45^{\mathrm{e}}$ & $4.23^{\mathrm{b}}$ & $11.97^{\mathrm{b}}$ & $25.59^{b}$ & $9.92^{\mathrm{de}}$ & $25.38^{\mathrm{a}}$ & $2.18^{c}$ & $0.74^{\mathrm{b}}$ & 55.02 & 37.48 & 17.46 & 37.56 & 37.48 \\
\hline
\end{tabular}

${ }^{*}$ See Table 1. TCLS = Tulum cheese with Lactobacillus acidophilus stuffed into skin bag; TCLI = Tulum cheese with Lactobacillus acidophilus stuffed into small intestine; TCLA = Tulum cheese with Lactobacillus acidophilus stuffed into appendix; TCBS = Tulum cheese with Bifidobacterium animalis spp. lactis stuffed into skin bag; TCBI = Tulum cheese with Bifidobacterium animalis spp. lactis stuffed into small intestine; TCBA = Tulum cheese with Bifidobacterium animalis spp. lactis stuffed into appendix; TCMS = Tulum cheese with mix probiotic bacteria stuffed into skin bag; TCMI = Tulum cheese with mix probiotic bacteria stuffed into small intestine; TCMA = Tulum cheese with mix probiotic bacteria stuffed into appendix; CLA = Conjugated linolenic acid; SFA = Satured fatty acids; USFA = Unsatured fatty acids, SCFA = Short chain fatty acids (C:4-C:12); MCFA= Medium chain fatty acids (C:14-C:16); LCFA $=$ Long chain fatty acids $(\geq$ C:18) a-g $(\downarrow)$ The difference between the averages carrying the same letters is not statistically significant $(\mathrm{P}>0.05)$.

packing materials increased in all cheese samples during the 90-day aging period $(\mathrm{P}<0.05)$.

CLA values ranging from $0.38 \%$ to $0.51 \%$ at the beginning of the storage increased to the range of $0.66 \%-0.82 \%$ at the end of the storage. At the end of the aging period, the highest value, namely $0.82 \%$, was detected in the Tulum cheese samples that were produced with the addition of L. acidophilus bacteria and stuffed into the small intestine.

The saturated fatty acids ratio was detected as between $54.78 \%$ and $59.7 \%$ in the Tulum cheese that was produced by adding $L$. acidophilus probiotic bacteria, between $54.98 \%$ and $59.60 \%$ in the cheeses into which B. animalis spp. lactis was added and between $55.01 \%$ and $59.25 \%$ in the cheeses into which the mixture of L. acidophilus and B. animalis spp. lactis. At the end of the 90-day aging period, the highest value of unsaturated fatty acids, namely $37.55 \%$, was detected in the samples that were produced by adding L. acidophilus and stuffed into the appendix (Table 2).

During the ripening period, short chain fatty acids in the Tulum cheeses were determined to vary between $16.36 \%$ and $21.76 \%$, medium chain fatty acids between $37.44 \%$ and $39.43 \%$, and long chain fatty acids between $32.30 \%$ and $37.48 \%$ (Table 2). The detected values are similar to the values determined in the study of Sert et al. (2014). Short chain fatty acids have quite an 
importance in the cheese aroma (Buffa et al., 2001; Prandini et al., 2011; Raynal-Ljutovac et al., 2011).

On the other hand, although the amount of medium and long chain fatty acids is quantitatively important, they have no contribution to the formation of cheese aroma (Attaie \& Richter, 1996). Also, the probiotic culture added did not affect flavour scores of Tulum cheese (Tomar, 2018).

The ripening time influenced high significantly $(\mathrm{P}<0.0001)$ influenced volatile components of Tulum cheese samples. Esters which are responsible for the fruit flavor in cheese, are formed through two enzymatic reactions, esterification and alcoholysis (Liu et al., 2004). Esters are very important components for the aroma of Erzincan Tulum cheese. Among the esters detected in Tulum cheese samples, the ethyl esters constitute the most important group (Hayaloglu et al., 2007).

Esters are important aroma compounds due to their low threshold values and ability to mask off-odours caused by high amounts of short-chain FFAs, methyl ketones, and amines (Holland et al., 2005). The concentrations of ethyl acetate, ethyl butanoate, ethyl lactate, propyl acetate, and 3- methylbutyl acetate were high and they were principal volatile compounds in the cheeses (Hayaloglu, 2009). Esters contribute to the cheese aroma as a fruit and flower aroma by softening the strength or sharpness of the acid or ketones (Hayaloglu \& Karabulut, 2013). Amount of the esters of the samples increased throughout the ripening time $(\mathrm{P}<0.05)$ (Table 3$)$.

During the 90-day ripening period, 3-methyl-1-butanol acetate (isoamyl acetate) was the ester detected at the highest ratio in the Tulum cheese samples. This compound was followed by ethylcapronate, ethylacetate, isoamyl butyrate, and propylhexanoat, respectively (Table 4). The values detected are similar to those of Cakir et al. (2016). Also, Hayaloglu et al. (2007) stated that they identified 16 esters in the Tulum cheese samples which they ripened in 90 days and the majority of these were ethyl esters. Similar esters were also detected in Parmigiano-Reggiano, Minas and Sepet cheeses (Qian \& Reineccius, 2002; Nogueira et al., 2005; Ercan et al., 2011).

In the cheese samples which were produced by adding the L. acidophilus and stuffed into the small small intestine, the amounts of ester were detected as the highest, whereas in the cheeses which were produced with the addition of $B$. animalis spp. lactis and aged by stuffing into the small small intestine the amounts of ester were detected as the lowest $(\mathrm{P}<0.05)$.

Ketones are the components responsible for the acute smell that occurs in cheeses especially after the ripening (Dunn \& Lindsay, 1985), and methyl ketone concentrations

Table 3. Effect of ripening time, packaging material and probiotic cultures on fatty acid distribution, $\mathrm{pH}$, ripening index and volatile composition of tulum cheese samples.

\begin{tabular}{|c|c|c|c|c|c|c|c|c|c|c|c|}
\hline Ripening Time (Day) & $\mathrm{C} 4.0$ & C6.0 & $\mathrm{C} 8.0$ & $\mathrm{C} 10.0$ & $\mathrm{C} 12.0$ & C14.0 & $\mathrm{C} 16.0$ & $\mathrm{C} 18.0$ & $\mathrm{C} 18: 1$ & C18:2 & CLA \\
\hline 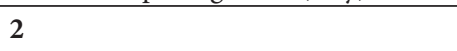 & $1.62^{c}$ & $2.19^{\mathrm{b}}$ & $2.56^{\mathrm{b}}$ & $8.46^{\mathrm{b}}$ & $5.19^{\mathrm{a}}$ & $12.89^{\mathrm{a}}$ & $25.19^{c}$ & $9.91^{\mathrm{c}}$ & $23,11^{\mathrm{c}}$ & $1,943^{c}$ & $0,46^{\mathrm{d}}$ \\
\hline 30 & $1.54^{\mathrm{d}}$ & $1.77^{\mathrm{d}}$ & $2.05^{\mathrm{d}}$ & $6.99^{\mathrm{d}}$ & $4.26^{\mathrm{b}}$ & $12.30^{\mathrm{b}}$ & $26.77^{\mathrm{a}}$ & $10.92^{\mathrm{a}}$ & $23,75^{\mathrm{b}}$ & $2,16^{\mathrm{ab}}$ & $0,52^{\mathrm{c}}$ \\
\hline 60 & $2.59^{\mathrm{a}}$ & $2.73^{\mathrm{a}}$ & $3.19^{\mathrm{a}}$ & $8.84^{\mathrm{a}}$ & $4.26^{\mathrm{b}}$ & $10.96^{c}$ & $26.84^{\mathrm{a}}$ & $10.75^{\mathrm{b}}$ & $19,89^{\mathrm{d}}$ & $2,11^{\mathrm{b}}$ & $0,60^{\mathrm{b}}$ \\
\hline 90 & $1.80^{\mathrm{b}}$ & $1.87^{\mathrm{c}}$ & $2.15^{\mathrm{c}}$ & $7.46^{\mathrm{c}}$ & $4.26^{\mathrm{b}}$ & $11.98^{\mathrm{b}}$ & $25.52^{\mathrm{b}}$ & $9.94^{\mathrm{c}}$ & $25,27^{\mathrm{a}}$ & $2,18^{\mathrm{a}}$ & $0,73^{\mathrm{a}}$ \\
\hline Packaging Material & C4.0 & C6.0 & $\mathrm{C} 8.0$ & $\mathrm{C} 10.0$ & $\mathrm{C} 12.0$ & $\mathrm{C} 14.0$ & $\mathrm{C} 16.0$ & C18.0 & $\mathrm{C} 18: 1$ & $\mathrm{C} 18: 2$ & CLA \\
\hline Skin Bag & $1.88^{\mathrm{a}}$ & $2.15^{\mathrm{a}}$ & $2.50^{\mathrm{a}}$ & $7.94^{\mathrm{a}}$ & $4.50^{\mathrm{a}}$ & $11.85^{\mathrm{a}}$ & $26.08^{a}$ & $10.42^{\mathrm{a}}$ & $23,00^{\mathrm{a}}$ & $2,09^{a}$ & $0,53^{\mathrm{b}}$ \\
\hline Intestine & $1.89^{\mathrm{a}}$ & $2.14^{\mathrm{a}}$ & $2.46^{\mathrm{a}}$ & $7.97^{\mathrm{a}}$ & $4.48^{\mathrm{a}}$ & $12.11^{\mathrm{a}}$ & $26.07^{a}$ & $10.34^{\mathrm{a}}$ & $22,97^{a}$ & $2,10^{\mathrm{a}}$ & $0,61^{\mathrm{a}}$ \\
\hline Appendix & $1.89^{\mathrm{a}}$ & $2.14^{\mathrm{a}}$ & $2.51^{\mathrm{b}}$ & $7.91^{\mathrm{a}}$ & $4.50^{\mathrm{a}}$ & $12.14^{\mathrm{a}}$ & $26.09^{\mathrm{a}}$ & $10.38^{\mathrm{a}}$ & $23,05^{\mathrm{a}}$ & $2,10^{\mathrm{a}}$ & $0,60^{\mathrm{a}}$ \\
\hline Probiotic Culture & C4.0 & C6.0 & $\mathrm{C} 8.0$ & $\mathrm{C} 10.0$ & $\mathrm{C} 12.0$ & C14.0 & $\mathrm{C} 16.0$ & C18.0 & $\mathrm{C} 18: 1$ & C18:2 & CLA \\
\hline Lactobacillus acidophilus & $1.89^{\mathrm{a}}$ & $2.16^{\mathrm{a}}$ & $2.49^{\mathrm{a}}$ & $7.97^{\mathrm{a}}$ & $4.50^{\mathrm{a}}$ & $12.12^{\mathrm{a}}$ & $26.08^{\mathrm{a}}$ & $10.45^{\mathrm{a}}$ & $23,05^{\mathrm{a}}$ & $2,10^{\mathrm{a}}$ & $0,58^{\mathrm{a}}$ \\
\hline Bifidobacterium animalis spp. lactis & $1.87^{\mathrm{a}}$ & $2.14^{\mathrm{ab}}$ & $2.48^{\mathrm{a}}$ & $7.93^{\mathrm{b}}$ & $4.48^{\mathrm{a}}$ & $12.12^{\mathrm{a}}$ & $26.11^{\mathrm{a}}$ & $10.35^{\mathrm{a}}$ & $22,97^{\mathrm{ab}}$ & $2,10^{\mathrm{a}}$ & $0,59^{\mathrm{a}}$ \\
\hline MIX & $1.91^{\mathrm{a}}$ & $2.12^{\mathrm{b}}$ & $2.50^{\mathrm{a}}$ & $7.92^{\mathrm{b}}$ & $4.49^{\mathrm{a}}$ & $11.86^{\mathrm{a}}$ & $26.05^{\mathrm{a}}$ & $10.34^{\mathrm{a}}$ & $23,01^{\mathrm{b}}$ & $2,08^{\mathrm{a}}$ & $0,57^{\mathrm{a}}$ \\
\hline Ripening Time (Day) & $\mathrm{pH}$ & \multicolumn{2}{|c|}{$\begin{array}{l}\text { Ripening } \\
\text { Index }\end{array}$} & Aldehydes & \multicolumn{2}{|c|}{ Ketones } & Esters & Terpenes & \multicolumn{2}{|c|}{ Alcohols } & $\begin{array}{c}\text { Carboxylic } \\
\text { acids }\end{array}$ \\
\hline 2 & $5.05^{\mathrm{a}}$ & \multicolumn{2}{|c|}{$6.92^{\mathrm{d}}$} & $119.83^{\mathrm{d}}$ & \multicolumn{2}{|c|}{$135.28^{\mathrm{d}}$} & $412.39^{c}$ & $115.27^{\mathrm{d}}$ & \multicolumn{2}{|c|}{$296.89^{d}$} & $3702.75^{c}$ \\
\hline 30 & $4.91^{\mathrm{b}}$ & \multicolumn{2}{|c|}{$9.59^{c}$} & $179.79^{c}$ & 313. & \multicolumn{2}{|c|}{$1247.57^{\mathrm{bc}}$} & $227.73^{c}$ & \multicolumn{2}{|c|}{$900.94^{c}$} & $5143.62^{\mathrm{b}}$ \\
\hline 60 & $4.79^{c}$ & \multicolumn{2}{|c|}{$13.49^{\mathrm{b}}$} & $294.64^{\mathrm{b}}$ & 595. & \multicolumn{2}{|c|}{$1884.51^{\mathrm{b}}$} & $311.79^{\mathrm{b}}$ & \multicolumn{2}{|c|}{$1324.36^{\mathrm{b}}$} & $6400.02^{\mathrm{ab}}$ \\
\hline 90 & $4.65^{\mathrm{d}}$ & \multicolumn{2}{|c|}{$21.37^{\mathrm{a}}$} & $315.89^{\mathrm{a}}$ & 880.2 & \multicolumn{2}{|c|}{$3014.58^{\mathrm{a}}$} & $429.66^{\mathrm{a}}$ & 1631 & & $6719.21^{\mathrm{a}}$ \\
\hline Packaging Material & $\mathrm{pH}$ & & & Aldehydes & Keto & & Esters & Terpenes & Alcc & hols & $\begin{array}{l}\text { Carboxylic } \\
\text { acids }\end{array}$ \\
\hline Skin Bag & $4.84^{\mathrm{a}}$ & & & $229.81^{c}$ & 826. & & $2137.52^{\mathrm{b}}$ & $318.96^{\mathrm{b}}$ & 1500 & & $7331.46^{\mathrm{a}}$ \\
\hline Intestine & $4.83^{\mathrm{a}}$ & & & $304.16^{\mathrm{b}}$ & 527.3 & & $2292.36^{\mathrm{a}}$ & $401.60^{\mathrm{a}}$ & 1343 & & $6498.49^{\mathrm{b}}$ \\
\hline Appendix & $4.86^{\mathrm{a}}$ & & & $376.18^{\mathrm{a}}$ & 570.7 & & $2129.17^{\mathrm{b}}$ & $363.89^{\mathrm{b}}$ & 1308 & & $7398.76^{\mathrm{a}}$ \\
\hline Probiotic Culture & $\mathrm{pH}$ & & & Aldehydes & Keto & & Esters & Terpenes & Alcc & hols & $\begin{array}{l}\text { Carboxylic } \\
\text { acids }\end{array}$ \\
\hline Lactobacillus acidophilus & $4.85^{\mathrm{a}}$ & & & $322.05^{\mathrm{a}}$ & 810. & & $2447.19^{\mathrm{a}}$ & $415.55^{\mathrm{a}}$ & 1604 & & $7205.51^{b}$ \\
\hline Bifidobacterium animalis spp. lactis & $4.83^{\mathrm{a}}$ & & & $331.03^{\mathrm{a}}$ & 461. & & $1936.21^{\mathrm{c}}$ & $312.44^{\mathrm{b}}$ & 1207 & & $7283.76^{\mathrm{b}}$ \\
\hline MIX & $4.84^{\mathrm{a}}$ & & & $325.70^{\mathrm{a}}$ & 704. & & $2175.65^{\mathrm{b}}$ & $356.46^{\mathrm{b}}$ & 1341 & $06^{\mathrm{ab}}$ & $7476.33^{\mathrm{a}}$ \\
\hline
\end{tabular}

CLA = Conjugated linolenic acid. ${ }^{\text {ad }}(\downarrow)$ The difference between the averages carrying the same letters is not statistically significant $(\mathrm{P}>0.05)$. 
Table 4. Esters detected in Tulum cheese samples during ripening $(\mu \mathrm{g} / 100 \mathrm{~g})$.

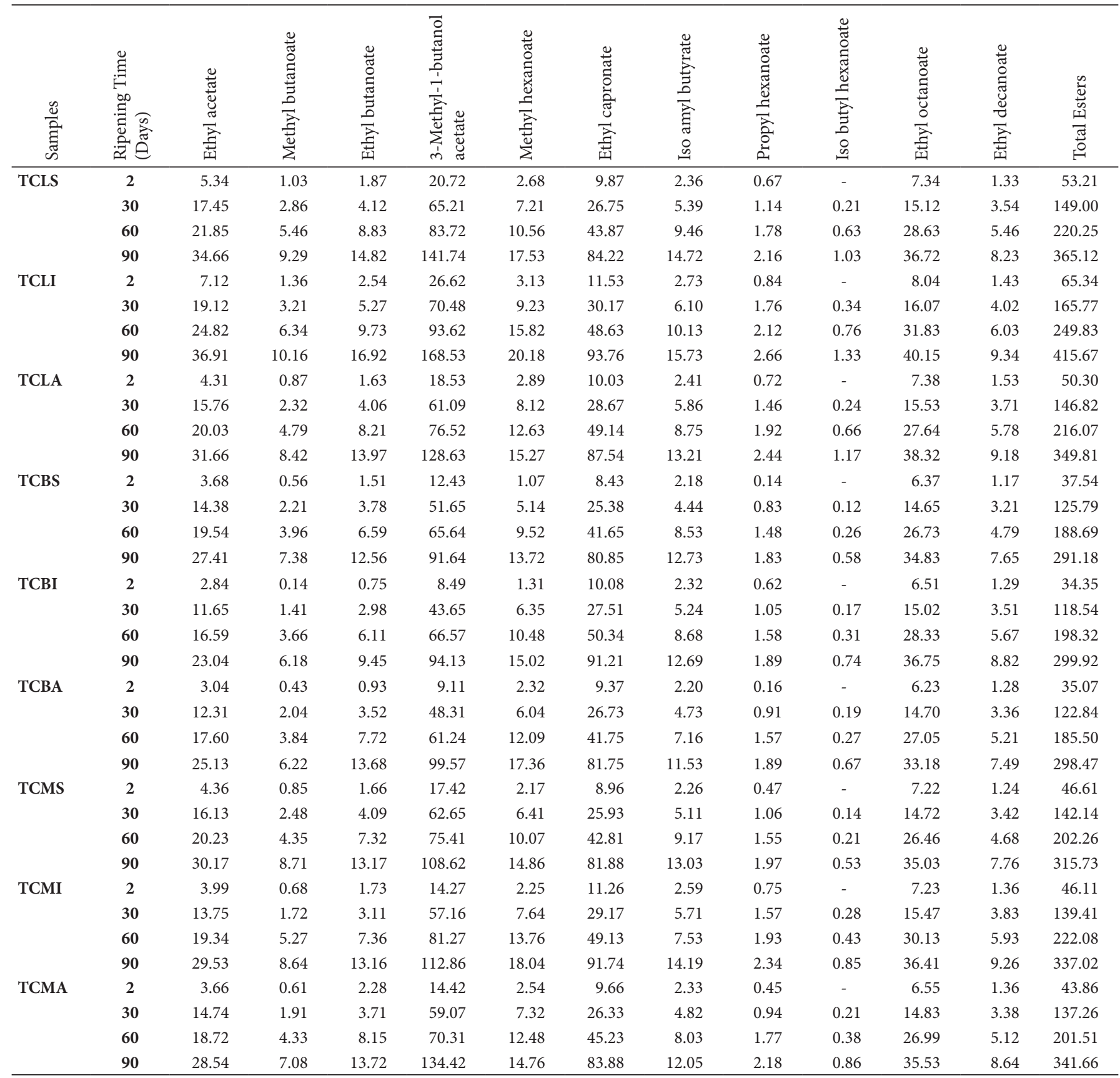

TCLS = Tulum cheese with Lactobacillus acidophilus stuffed into skin bag; TCLI = Tulum cheese with Lactobacillus acidophilus stuffed into small intestine; TCLA = Tulum cheese with Lactobacillus acidophilus stuffed into appendix; TCBS = Tulum cheese with Bifidobacterium animalis spp. lactis stuffed into skin bag; TCBI = Tulum cheese with Bifidobacterium animalis spp. lactis stuffed into small intestine; TCBA = Tulum cheese with Bifidobacterium animalis spp. lactis stuffed into appendix; TCMS = Tulum cheese with mix probiotic bacteria stuffed into skin bag; TCMI = Tulum cheese with mix probiotic bacteria stuffed into small intestine; TCMA = Tulum cheese with mix probiotic bacteria stuffed into appendix.

that are especially reduced to secondary alcohols are important components in terms of characterizing cheese aroma (Hayaloglu et al., 2007). During the ripening, 5 different ketone group existences were detected. Of these, it was determined that the highest amount belonged to 2-Pentanone. Throughout the ripening, amounts of ketone increased in all of the cheese samples $(\mathrm{P}<0.05)$. At the end of 90 days storage period, the highest amount of ketone was observed in 2-Pentanone with a value of $46.23(\mu \mathrm{g} / 100 \mathrm{~g})$ in the sample that was produced with $L$. acidophilus additive and stuffed into the Tulum cheese (Table 5). The highest values of other ketones that were detected in a similar way were detected in the same sample. The lowest amount of ketones that were detected at the end of the storage period was observed in the cheese samples that $B$. animalis spp. lactis were added during the production and ripened by filling into the small intestine with $3.64(\mu \mathrm{g} / 100 \mathrm{~g})(\mathrm{P}<0.05)$ (Table 5). Values that were obtained in the study are similar to the results of Cakir et al. (2016). Hayaloglu et al. (2008) stated that the most abundant ketones in Tulum cheeses were 2-butanone and diacetyl. 
Aldehydes are the compounds that are produced by catabolism of fatty acids or amino acids through decarboxylation or deamination (McSweeney \& Sousa, 2000). Aldehydes are transient compounds and do not accumulate in cheese significantly as they transform into alcohols or corresponding acids rapidly (Molimard \& Spinnler, 1996).

Six different aldehydes existences were detected in Tulum cheeses that were produced by adding different probiotic bacteria and ripened by being stuffed into three different packaging materials throughout the ripening. Observed amounts of aldehydes increased in all of the samples throughout the storage period $(\mathrm{P}<0.05)$ (Table 5). The highest amount of aldehyde in all of the samples throughout the ripening period was hexanal, and heptanal and nonanal followed it respectively. At the end of 90 days storage period, the highest amount of hexanal was detected in the samples that $L$. acidophilus additive was used in the production and was stuffed into small intestine with a value of $38.44(\mu \mathrm{g} / 100 \mathrm{~g})$. Cheese samples that B. animalis spp. lactis were added in the production and were stuffed into the appendix with the value of $33.17(\mu \mathrm{g} / 100 \mathrm{~g})$ followed it respectively $(\mathrm{P}<0.05)$.

Table 5. Ketones and Aldehydes detected in Tulum cheese samples during ripening ( $\mu \mathrm{g} / 100 \mathrm{~g})$.

\begin{tabular}{|c|c|c|c|c|c|c|c|c|c|c|c|c|c|c|}
\hline 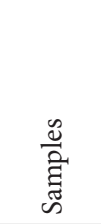 & 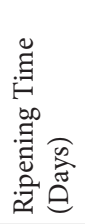 & 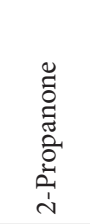 & 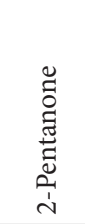 & 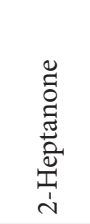 & 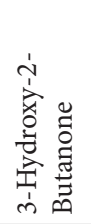 & 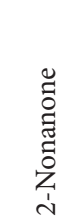 & 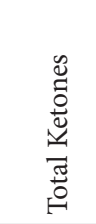 & 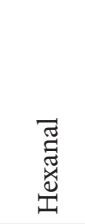 & 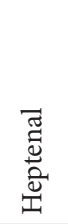 & 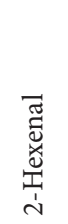 & $\begin{array}{l}\text { Zే } \\
\text { Z̃ } \\
\text { Z }\end{array}$ & 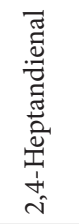 & 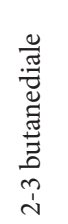 & 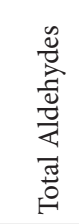 \\
\hline \multirow[t]{4}{*}{ TCLS } & 2 & 0.17 & 13.14 & 7.76 & 1.42 & 1.24 & 23.73 & 9.27 & 2.11 & - & 0.64 & - & - & 12.02 \\
\hline & 30 & 2.04 & 27.45 & 16.14 & 4.27 & 4.11 & 54.01 & 15.63 & 3.18 & 0.66 & 1.18 & - & 0.27 & 20.92 \\
\hline & 60 & 6.41 & 36.12 & 28.65 & 17.24 & 16.54 & 104.96 & 19.41 & 4.07 & 1.09 & 1.31 & 0.36 & 0.66 & 26.90 \\
\hline & 90 & 10.11 & 46.23 & 35.13 & 31.83 & 33.45 & 156.75 & 23.36 & 4.13 & 1.27 & 2.02 & 0.67 & 1.23 & 32.68 \\
\hline \multirow[t]{4}{*}{ TCLI } & 2 & - & 9.81 & 4.45 & 0.63 & 0.52 & 15.41 & 11.35 & 2.37 & - & 1.12 & - & 0.42 & 15.26 \\
\hline & 30 & 0.44 & 20.64 & 11.09 & 1.18 & 1.54 & 34.89 & 19.67 & 3.88 & 0.94 & 1.74 & 0.11 & 1.16 & 27.50 \\
\hline & 60 & 2.71 & 31.16 & 19.61 & 9.22 & 8.23 & 70.93 & 21.43 & 4.67 & 1.64 & 2.35 & 1.21 & 1.68 & 32.98 \\
\hline & 90 & 4.56 & 40.75 & 27.35 & 17.95 & 15.23 & 105.84 & 38.44 & 5.43 & 2.37 & 3.65 & 1.93 & 2.07 & 53.89 \\
\hline \multirow[t]{4}{*}{ TCLA } & 2 & - & 10.64 & 6.26 & 0.94 & 0.25 & 18.09 & 13.11 & 1.65 & - & 0.14 & - & - & 14.90 \\
\hline & 30 & 0.73 & 23.15 & 12.83 & 2.54 & 2.86 & 42.11 & 16.65 & 2.85 & - & 0.88 & - & 0.18 & 20.56 \\
\hline & 60 & 3.14 & 31.26 & 19.32 & 10.04 & 9.11 & 72.87 & 20.33 & 4.57 & 0.32 & 1.65 & 0.24 & 0.53 & 27.64 \\
\hline & 90 & 5.44 & 42.09 & 23.09 & 21.86 & 18.47 & 110.95 & 26.42 & 5.27 & 0.83 & 2.13 & 1.01 & 1.14 & 36.80 \\
\hline \multirow{4}{*}{ TCBS } & 2 & 0.09 & 7.26 & 4.84 & 1.07 & 0.87 & 14.13 & 8.65 & 0.71 & - & - & - & - & 9.36 \\
\hline & 30 & 1.13 & 19.36 & 8.45 & 3.76 & 4.02 & 36.72 & 12.24 & 1.48 & - & 0.36 & - & - & 14.08 \\
\hline & 60 & 3.67 & 31.76 & 19.21 & 8.54 & 8.54 & 71.72 & 16.41 & 2.23 & 0.34 & 0.92 & - & 0.16 & 20.06 \\
\hline & 90 & 7.41 & 38.54 & 27.36 & 16.33 & 15.54 & 105.18 & 19.65 & 2.76 & 0.82 & 1.54 & 0.18 & 0.21 & 25.16 \\
\hline \multirow[t]{4}{*}{ TCBI } & 2 & - & 4.12 & 0.54 & - & - & 4.66 & 10.85 & 1.05 & - & - & - & - & 11.90 \\
\hline & 30 & 0.25 & 11.84 & 1.63 & 0.65 & 0.91 & 15.28 & 13.32 & 1.69 & - & 0.74 & - & 0.09 & 15.84 \\
\hline & 60 & 2.08 & 23.97 & 8.25 & 1.06 & 1.12 & 36.48 & 20.53 & 2.07 & 0.61 & 1.27 & 0.77 & 0.26 & 25.51 \\
\hline & 90 & 5.22 & 31.42 & 14.86 & 3.64 & 3.57 & 58.71 & 27.17 & 2.19 & 1.05 & 2.11 & 1.48 & 0.71 & 34.71 \\
\hline \multirow[t]{4}{*}{ TCBA } & 2 & 0.27 & 5.76 & 1.05 & 0.84 & 0.61 & 8.53 & 14.62 & 0.96 & - & - & - & - & 15.58 \\
\hline & 30 & 1.63 & 13.48 & 3.27 & 1.21 & 1.26 & 20.85 & 20.01 & 1.34 & - & 0.44 & - & - & 21.79 \\
\hline & 60 & 4.02 & 19.33 & 6.63 & 3.12 & 3.53 & 36.63 & 26.53 & 1.77 & 0.15 & 1.02 & 0.32 & 0.13 & 29.92 \\
\hline & 90 & 6.35 & 25.48 & 11.27 & 4.56 & 5.01 & 52.67 & 33.17 & 1.96 & 0.28 & 1.72 & 0.83 & 0.53 & 38.49 \\
\hline \multirow[t]{4}{*}{ TCMS } & 2 & 0.13 & 10.61 & 5.02 & 1.76 & 1.17 & 18.69 & 9.05 & 0.85 & - & 0.14 & - & - & 10.04 \\
\hline & 30 & 1.42 & 24.78 & 11.01 & 4.11 & 4.27 & 45.59 & 13.16 & 1.86 & 0.16 & 0.56 & - & - & 15.74 \\
\hline & 60 & 4.28 & 30.76 & 23.75 & 11.56 & 10.47 & 80.82 & 14.13 & 2.54 & 0.84 & 1.32 & 0.16 & 0.27 & 19.26 \\
\hline & 90 & 8.13 & 38.16 & 29.12 & 19.46 & 19.12 & 113.99 & 16.23 & 3.36 & 1.32 & 1.73 & 0.33 & 0.62 & 23.59 \\
\hline \multirow[t]{4}{*}{ TCMI } & 2 & - & 7.23 & 6.41 & 1.08 & 0.85 & 15.57 & 11.03 & 1.35 & - & 0.45 & - & - & 12.83 \\
\hline & 30 & 0.31 & 16.66 & 7.13 & 3.06 & 1.32 & 28.48 & 13.22 & 2.09 & 0.23 & 1.24 & - & 0.18 & 16.96 \\
\hline & 60 & 2.27 & 29.13 & 15.35 & 6.46 & 5.33 & 58.54 & 18.45 & 2.77 & 1.21 & 1.63 & 0.81 & 0.61 & 25.48 \\
\hline & 90 & 4.74 & 36.34 & 20.35 & 10.51 & 10.64 & 82.58 & 20.54 & 3.29 & 1.65 & 2.88 & 1.93 & 1.01 & 31.30 \\
\hline \multirow[t]{4}{*}{ TCMA } & 2 & 0.84 & 7.21 & 5.46 & 1.45 & 1.51 & 16.47 & 16.52 & 1.06 & - & 0.36 & - & - & 17.94 \\
\hline & 30 & 1.56 & 19.41 & 10.06 & 2.03 & 2.44 & 35.5 & 23.15 & 1.94 & 0.13 & 1.18 & - & - & 26.40 \\
\hline & 60 & 3.72 & 24.13 & 19.76 & 7.66 & 7.21 & 62.48 & 28.21 & 2.27 & 0.45 & 1.72 & 054 & 0.24 & 86.89 \\
\hline & 90 & 6.01 & 36.43 & 24.32 & 13.85 & 12.97 & 93.58 & 31.17 & 2.96 & 0.88 & 2.33 & 1.05 & 0.88 & 39.27 \\
\hline
\end{tabular}

TCLS = Tulum cheese with Lactobacillus acidophilus stuffed into skin bag; TCLI = Tulum cheese with Lactobacillus acidophilus stuffed into small intestine; TCLA = Tulum cheese with Lactobacillus acidophilus stuffed into appendix; TCBS = Tulum cheese with Bifidobacterium animalis spp. lactis stuffed into skin bag; TCBI = Tulum cheese with Bifidobacterium animalis spp. lactis stuffed into small intestine; TCBA = Tulum cheese with Bifidobacterium animalis spp. lactis stuffed into appendix; TCMS = Tulum cheese with mix probiotic bacteria stuffed into skin bag; TCMI = Tulum cheese with mix probiotic bacteria stuffed into small intestine; TCMA = Tulum cheese with mix probiotic bacteria stuffed into appendix. 
Terpenes are the compounds that exist in milk naturally (Curioni \& Bosset, 2002) and they pass to milk originating from the forage or the plants in the pastures (Nogueira et al., 2005). Throughout the ripening, similar to the studies of Cakir et al. (2016) and Akpinar et al. (2017), seven different terpenes were detected, and their amounts increased with the ripening time $(\mathrm{P}<0.05)$ (Table 6). In all of the Tulum cheese samples, $\alpha$-Pinene and Cymol concentrations are the compounds that exist the most. In the cheese samples that $L$. acidophilus was added to production, terpenes were detected in higher amounts. The samples that the mixture of $L$. acidophilus and B. animalis spp. lactis were added and the samples that $B$. animalis spp. lactis were added followed it respectively. According to the packaging material used, the samples that had the highest amount of terpene concentration were the ones that were stuffed into small small intestine $(\mathrm{P}<0.05)$.
Alcohols are accepted as significant volatile compounds that can contribute to the taste of cheeses and cause creation of an alcoholic, sweet, fruity and strong aroma (Barron et al., 2005; Hayaloglu et al., 2007).

In Tulum cheese that is produced by using raw milk, high alcohol concentrations can be reached (Hayaloglu, 2009; Cakir et al., 2016). But being subjected to pasteurization process before the milk is processed into the cheese cause the decrease of alcohol concentration that would occur (Ortigosa et al., 2005). Alcohols can be synthesized in many ways such as lactose, amino acid metabolism, and degradation of methyl ketones (Molimard \& Spinnler, 1996).

While primary alcohols are derived from amino acids that are produced by aldehyde degradation, secondary alcohols that contain 2-pentonal and 2-nanonal are created by reduction of

Table 6. Terpenes detected in Tulum cheese samples during ripening $(\mu \mathrm{g} / 100 \mathrm{~g})$.

\begin{tabular}{|c|c|c|c|c|c|c|c|c|c|}
\hline Samples & $\begin{array}{c}\text { Ripening } \\
\text { Time (Days) }\end{array}$ & a-Pinene & $\begin{array}{c}\alpha \\
\text { Phellandrene }\end{array}$ & Cymol & Camphene & $\beta$-Pinene & Limonene & p-Cymene & $\begin{array}{c}\text { Total } \\
\text { Terpenes }\end{array}$ \\
\hline \multirow[t]{4}{*}{ TCLS } & 2 & 7.32 & 0.54 & 4.32 & 0.15 & 0.35 & 0.71 & 0.04 & 13.43 \\
\hline & 30 & 10.34 & 1.86 & 7.43 & 0.59 & 1.08 & 2.64 & 0.14 & 24.08 \\
\hline & 60 & 13.56 & 2.43 & 10.15 & 0.71 & 1.31 & 3.48 & 0.19 & 31.83 \\
\hline & 90 & 18.23 & 4.64 & 18.42 & 1.41 & 2.69 & 6.63 & 0.36 & 52.38 \\
\hline \multirow[t]{4}{*}{ TCLI } & 2 & 9.32 & 0.83 & 5.16 & 0.23 & 0.42 & 1.11 & 0.06 & 17.13 \\
\hline & 30 & 13.28 & 2.54 & 8.60 & 0.77 & 1.48 & 3.64 & 0.19 & 30.50 \\
\hline & 60 & 19.66 & 4.02 & 14.23 & 1.23 & 2.21 & 5.78 & 0.31 & 47.44 \\
\hline & 90 & 24.65 & 4.83 & 20.38 & 1.44 & 2.78 & 6.91 & 0.37 & 61.36 \\
\hline \multirow[t]{4}{*}{ TCLA } & 2 & 8.21 & 0.70 & 5.04 & 0.20 & 0.34 & 1.02 & 0.05 & 15.56 \\
\hline & 30 & 12.62 & 2.31 & 7.88 & 0.70 & 1.30 & 3.31 & 0.18 & 28.30 \\
\hline & 60 & 16.32 & 3.65 & 11.05 & 1.10 & 2.06 & 5.23 & 0.28 & 39.69 \\
\hline & 90 & 20.11 & 4.45 & 18.72 & 1.34 & 2.54 & 6.35 & 0.34 & 53.85 \\
\hline \multirow[t]{4}{*}{ TCBS } & 2 & 5.21 & 0.24 & 2.09 & 0.07 & 0.19 & 0.34 & 0.02 & 8.16 \\
\hline & 30 & 9.31 & 1.64 & 6.32 & 0.50 & 0.92 & 2.33 & 0.13 & 21.15 \\
\hline & 60 & 10.46 & 1.93 & 9.63 & 0.55 & 1.09 & 2.76 & 0.15 & 26.57 \\
\hline & 90 & 15.13 & 2.38 & 14.26 & 0.76 & 1.33 & 3.41 & 0.18 & 37.45 \\
\hline \multirow[t]{4}{*}{ TCBI } & 2 & 7.13 & 0.48 & 2.97 & 0.11 & 0.27 & 0.61 & 0.04 & 11.61 \\
\hline & 30 & 10.14 & 1.83 & 7.27 & 0.58 & 1.08 & 2.62 & 0.14 & 23.66 \\
\hline & 60 & 15.43 & 2.27 & 10.83 & 0.69 & 1.24 & 3.25 & 0.17 & 33.88 \\
\hline & 90 & 18.66 & 2.65 & 16.31 & 0.81 & 1.45 & 3.80 & 0.20 & 43.88 \\
\hline \multirow[t]{4}{*}{ TCBA } & 2 & 7.13 & 0.33 & 2.27 & 0.10 & 0.14 & 0.47 & 0.03 & 10.47 \\
\hline & 30 & 9.67 & 1.78 & 6.52 & 0.54 & 1.00 & 2.55 & 0.14 & 22.20 \\
\hline & 60 & 14.43 & 2.15 & 10.01 & 0.62 & 1.21 & 3.08 & 0.16 & 31.66 \\
\hline & 90 & 18.07 & 2.48 & 15.29 & 0.71 & 1.43 & 3.58 & 0.19 & 41.75 \\
\hline \multirow[t]{4}{*}{ TCMS } & 2 & 6.68 & 0.51 & 3.49 & 0.17 & 0.26 & 0.73 & 0.04 & 11.88 \\
\hline & 30 & 10.15 & 1.85 & 7.33 & 0.57 & 1.01 & 2.65 & 0.14 & 23.70 \\
\hline & 60 & 11.21 & 2.33 & 8.83 & 0.78 & 1.31 & 3.34 & 0.18 & 27.98 \\
\hline & 90 & 16.08 & 2.71 & 15.07 & 0.86 & 1.53 & 3.89 & 0.21 & 40.35 \\
\hline \multirow[t]{4}{*}{ TCMI } & 2 & 7.61 & 0.77 & 3.80 & 0.27 & 0.43 & 1.10 & 0.06 & 14.04 \\
\hline & 30 & 12.98 & 2.33 & 7.49 & 0.78 & 1.31 & 3.34 & 0.18 & 28.41 \\
\hline & 60 & 14.95 & 3.16 & 12.12 & 0.91 & 1.71 & 4.53 & 0.24 & 37.62 \\
\hline & 90 & 21.82 & 3.84 & 17.33 & 1.12 & 2.16 & 5.51 & 0.29 & 52.07 \\
\hline \multirow[t]{4}{*}{ TCMA } & 2 & 7.44 & 0.65 & 3.43 & 0.17 & 0.32 & 0.93 & 0.05 & 12.99 \\
\hline & 30 & 12.36 & 1.84 & 7.21 & 0.51 & 1.03 & 2.64 & 0.14 & 25.73 \\
\hline & 60 & 15.53 & 2.65 & 10.64 & 0.88 & 1.42 & 3.80 & 0.20 & 35.12 \\
\hline & 90 & 19.11 & 3.48 & 15.75 & 1.02 & 1.95 & 4.99 & 0.27 & 46.57 \\
\hline
\end{tabular}

TCLS = Tulum cheese with Lactobacillus acidophilus stuffed into skin bag; TCLI = Tulum cheese with Lactobacillus acidophilus stuffed into small intestine; TCLA = Tulum cheese with Lactobacillus acidophilus stuffed into appendix; TCBS = Tulum cheese with Bifidobacterium animalis spp. lactis stuffed into skin bag; TCBI = Tulum cheese with Bifidobacterium animalis spp. lactis stuffed into small intestine; TCBA = Tulum cheese with Bifidobacterium animalis spp. lactis stuffed into appendix; TCMS = Tulum cheese with mix probiotic bacteria stuffed into skin bag; TCMI = Tulum cheese with mix probiotic bacteria stuffed into small intestine; TCMA = Tulum cheese with mix probiotic bacteria stuffed into appendix. 
methyl ketones (Hayaloglu et al., 2007). Throughout the 90 days ripening period, it was detected that 9 different alcohols existed in total including primary, secondary and branched chains. Amount of the alcohols of the Tulum cheese samples increased during the ripening time $(\mathrm{P}<0.05)$ (Table 7). 3-methyl-1-butanol, ethanol and benzene ethanol were the most detected alcohols in the Tulum cheese samples similar to the results of Gun (2012) and Cakir et al. (2016). It was observed that in the cheeses that L. acidophilus was added in the production and was ripened by packaging in the Tulum there was much more alcohol $(104.63 \mu \mathrm{g} / 100 \mathrm{~g})$ compared to the other samples. This alcohol occurs by the reduction of the aldehydes that are produced from Leu catabolism (Curioni \& Bosset, 2002; Cakmakci et al., 2013). The amount of ethanol increased in all of the Tulum cheese samples throughout the storage period. The highest amount of ethanol $(50.14 \mu \mathrm{g} / 100 \mathrm{~g})$ was found in the cheese that B. animalis spp. lactis was added in the production and were ripened by packaging in the small intestine. Parallel to the results in the similar studies (Hayaloglu \& Brechany, 2007; Hayaloglu et al., 2007, 2008; Gun, 2012; Cakir et al., 2016) conducted, in the Tulum cheese samples, the existence of alcohol, which had branched chains and was stated that it contributed to cheese

Table 7. Alcohols detected in Tulum cheese samples during ripening $(\mu \mathrm{g} / 100 \mathrm{~g})$.

\begin{tabular}{|c|c|c|c|c|c|c|c|c|c|c|c|}
\hline 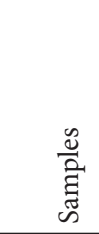 & 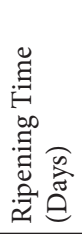 & 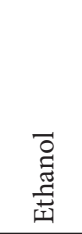 & 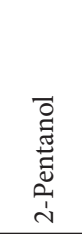 & 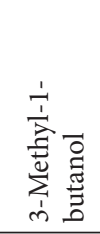 & 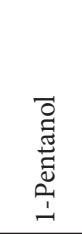 & 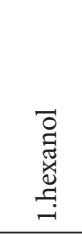 & 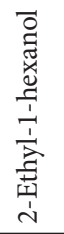 & 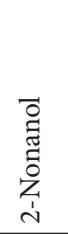 & 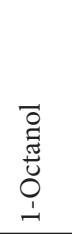 & 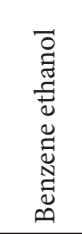 & $\begin{array}{l}\frac{n}{0} \\
\frac{3}{0} \\
\frac{0}{4} \\
\frac{\pi}{0} \\
\frac{0}{0}\end{array}$ \\
\hline \multirow[t]{4}{*}{ TCLS } & 2 & 2.43 & 1.32 & 25.52 & 2.18 & 0.77 & 0.71 & 0.22 & 0.06 & 6.45 & 39.66 \\
\hline & 30 & 30.65 & 4.54 & 62.11 & 5.13 & 2.63 & 1.64 & 0.74 & 0.22 & 10.33 & 117.99 \\
\hline & 60 & 44.22 & 10.32 & 85.24 & 9.23 & 5.99 & 2.24 & 1.69 & 0.50 & 17.39 & 176.82 \\
\hline & 90 & 48.15 & 16.74 & 104.63 & 10.78 & 9.71 & 4.16 & 2.74 & 0.81 & 21.13 & 218.85 \\
\hline \multirow[t]{4}{*}{ TCLI } & 2 & 2.16 & 1.87 & 20.54 & 2.86 & 1.09 & 1.14 & 0.31 & 0.09 & 9.92 & 39.98 \\
\hline & 30 & 23.65 & 4.71 & 51.23 & 5.89 & 2.73 & 2.42 & 0.77 & 0.23 & 16.74 & 108.37 \\
\hline & 60 & 38.65 & 14.64 & 73.45 & 10.14 & 8.50 & 4.83 & 2.39 & 0.71 & 21.62 & 174.93 \\
\hline & 90 & 32.45 & 19.32 & 94.34 & 11.33 & 11.21 & 5.34 & 3.16 & 0.93 & 29.13 & 207.21 \\
\hline \multirow[t]{4}{*}{ TCLA } & 2 & 2.29 & 1.55 & 22.38 & 2.45 & 0.90 & 1.07 & 0.25 & 0.07 & 7.13 & 38.09 \\
\hline & 30 & 21.76 & 4.66 & 57.65 & 5.41 & 2.70 & 2.31 & 0.76 & 0.22 & 12.71 & 108.18 \\
\hline & 60 & 36.54 & 10.65 & 82.03 & 9.76 & 6.18 & 4.52 & 1.74 & 0.51 & 18.53 & 170.46 \\
\hline & 90 & 32.64 & 17.32 & 98.36 & 10.89 & 10.05 & 5.14 & 2.83 & 0.83 & 26.17 & 204.23 \\
\hline \multirow[t]{4}{*}{ TCBS } & 2 & 1.09 & 0.75 & 18.27 & 1.27 & 0.44 & 0.44 & 0.12 & 0.04 & 4.64 & 27.06 \\
\hline & 30 & 24.12 & 3.81 & 50.28 & 4.24 & 2.21 & 1.06 & 0.62 & 0.18 & 8.42 & 94.94 \\
\hline & 60 & 42.24 & 6.53 & 68.43 & 7.53 & 3.79 & 1.73 & 1.07 & 0.31 & 13.62 & 145.25 \\
\hline & 90 & 50.14 & 12.53 & 85.26 & 9.74 & 7.27 & 3.24 & 2.05 & 0.60 & 17.20 & 188.03 \\
\hline \multirow[t]{4}{*}{ TCBI } & 2 & 0.87 & 1.03 & 14.53 & 2.08 & 0.60 & 1.27 & 0.17 & 0.05 & 5.73 & 26.33 \\
\hline & 30 & 19.12 & 4.06 & 44.21 & 5.11 & 2.36 & 1.93 & 0.66 & 0.20 & 10.13 & 87.78 \\
\hline & 60 & 26.45 & 7.21 & 55.25 & 8.66 & 4.18 & 3.51 & 1.18 & 0.35 & 15.46 & 122.25 \\
\hline & 90 & 26.13 & 13.41 & 64.82 & 10.47 & 7.78 & 4.82 & 2.19 & 0.65 & 19.56 & 149.83 \\
\hline \multirow[t]{4}{*}{ TCBA } & 2 & 0.77 & 0.92 & 16.29 & 1.32 & 0.53 & 1.01 & 0.15 & 0.04 & 6.21 & 27.24 \\
\hline & 30 & 15.64 & 3.90 & 48.33 & 4.75 & 2.26 & 1.88 & 0.64 & 0.19 & 9.65 & 87.24 \\
\hline & 60 & 21.45 & 6.68 & 51.83 & 6.94 & 3.88 & 3.13 & 1.09 & 0.32 & 14.24 & 109.56 \\
\hline & 90 & 20.34 & 12.53 & 66.94 & 10.02 & 7.27 & 4.35 & 2.05 & 0.60 & 18.02 & 142.12 \\
\hline \multirow[t]{4}{*}{ TCMS } & 2 & 2.34 & 1.17 & 22.72 & 1.38 & 0.68 & 0.62 & 0.19 & 0.06 & 5.17 & 34.33 \\
\hline & 30 & 26.87 & 4.27 & 54.96 & 4.66 & 2.48 & 1.72 & 0.70 & 0.21 & 9.21 & 105.08 \\
\hline & 60 & 38.36 & 10.14 & 73.12 & 8.11 & 5.88 & 2.13 & 1.66 & 0.49 & 15.15 & 155.04 \\
\hline & 90 & 45.23 & 14.61 & 93.71 & 10.27 & 8.48 & 3.76 & 2.39 & 0.70 & 18.53 & 197.68 \\
\hline \multirow[t]{4}{*}{ TCMI } & 2 & 1.76 & 1.52 & 16.17 & 2.34 & 0.88 & 1.19 & 0.25 & 0.07 & 10.05 & 34.23 \\
\hline & 30 & 19.52 & 4.14 & 46.21 & 5.31 & 2.40 & 2.17 & 0.68 & 0.20 & 12.31 & 92.94 \\
\hline & 60 & 28.56 & 12.47 & 54.21 & 9.12 & 7.24 & 2.37 & 2.04 & 0.60 & 17.50 & 134.11 \\
\hline & 90 & 27.53 & 17.54 & 66.81 & 10.77 & 10.18 & 4.33 & 2.87 & 0.85 & 25.12 & 166.00 \\
\hline \multirow[t]{4}{*}{ TCMA } & 2 & 1.04 & 1.17 & 17.38 & 1.44 & 0.68 & 1.09 & 0.19 & 0.06 & 6.92 & 29.97 \\
\hline & 30 & 20.22 & 3.96 & 52.11 & 5.19 & 2.30 & 2.18 & 0.65 & 0.19 & 11.62 & 98.42 \\
\hline & 60 & 30.34 & 8.82 & 62.32 & 7.36 & 5.12 & 3.96 & 1.44 & 0.43 & 16.15 & 135.94 \\
\hline & 90 & 27.32 & 11.22 & 74.24 & 11.11 & 6.51 & 4.82 & 1.83 & 0.54 & 19.73 & 157.32 \\
\hline
\end{tabular}

TCLS = Tulum cheese with Lactobacillus acidophilus stuffed into skin bag; TCLI = Tulum cheese with Lactobacillus acidophilus stuffed into small intestine; TCLA = Tulum cheese with Lactobacillus acidophilus stuffed into appendix; TCBS = Tulum cheese with Bifidobacterium animalis spp. lactis stuffed into skin bag; TCBI = Tulum cheese with Bifidobacterium animalis spp. lactis stuffed into small intestine; TCBA = Tulum cheese with Bifidobacterium animalis spp. lactis stuffed into appendix; TCMS = Tulum cheese with mix probiotic bacteria stuffed into skin bag; TCMI = Tulum cheese with mix probiotic bacteria stuffed into small intestine; TCMA = Tulum cheese with mix probiotic bacteria stuffed into appendix. 
aroma even in small amounts (Wolf et al., 2011; Cakmakci et al., 2013), was detected.

Many acids that exist in cheese are created as a result of lipolysis of milk fat (Urbach, 1997; Collins et al., 2003). Ethanoic (Acetic), Propanoic, pentanoic or octanoic acids are produced as a result of lipolysis or fermentation of lactose or lactic acid. But 2-methyl propanoic and 3-methyl propanoic acids are produced as a result of amino acid metabolism (Banks et al., 2001; Mallia et al., 2005).

However, acids are not only aroma components in cheese but also, they behave as precursors of very different compounds such as ketones, alcohols, lactones, aldehydes, and esters at the same time (Cakmakci et al., 2013). Nine different organic acids were detected in the Tulum cheese samples and all increased the ripening period $(\mathrm{P}<0.05)$ (Table 3$)$. Detected organic acids are the same as the ones that Hayaloglu et al. (2007) and Cakir et al. (2016) detected in their studies. Butanoic acid is the most found one in the cheese samples similar to the studies of Hayaloglu et al. (2007) and Hayaloglu \& Karabulut (2013). Butanoic acid is produced mainly by lipolysis (McSweeney \& Sousa, 2000). Acetic and propanoic acids follow it respectively. At the end of 90 days ripening period, the highest amount of butanoic acid $(261.39 \mu \mathrm{g} / 100 \mathrm{~g})$ (Table 8$)$ was detected in the cheese that was produced by adding the mixture of $L$. acidophilus and $B$. animalis spp. lactis and ripened by being stuffed into the appendix. The cheese samples that were produced with L. acidophilus additive and stored in Tulum packaging followed it with a value of $248.03 \mu \mathrm{g} / 100 \mathrm{~g}$.

Table 8. Carboxylic acids (CA) detected in Tulum cheese samples during ripening $(\mu \mathrm{g} / 100 \mathrm{~g})$.

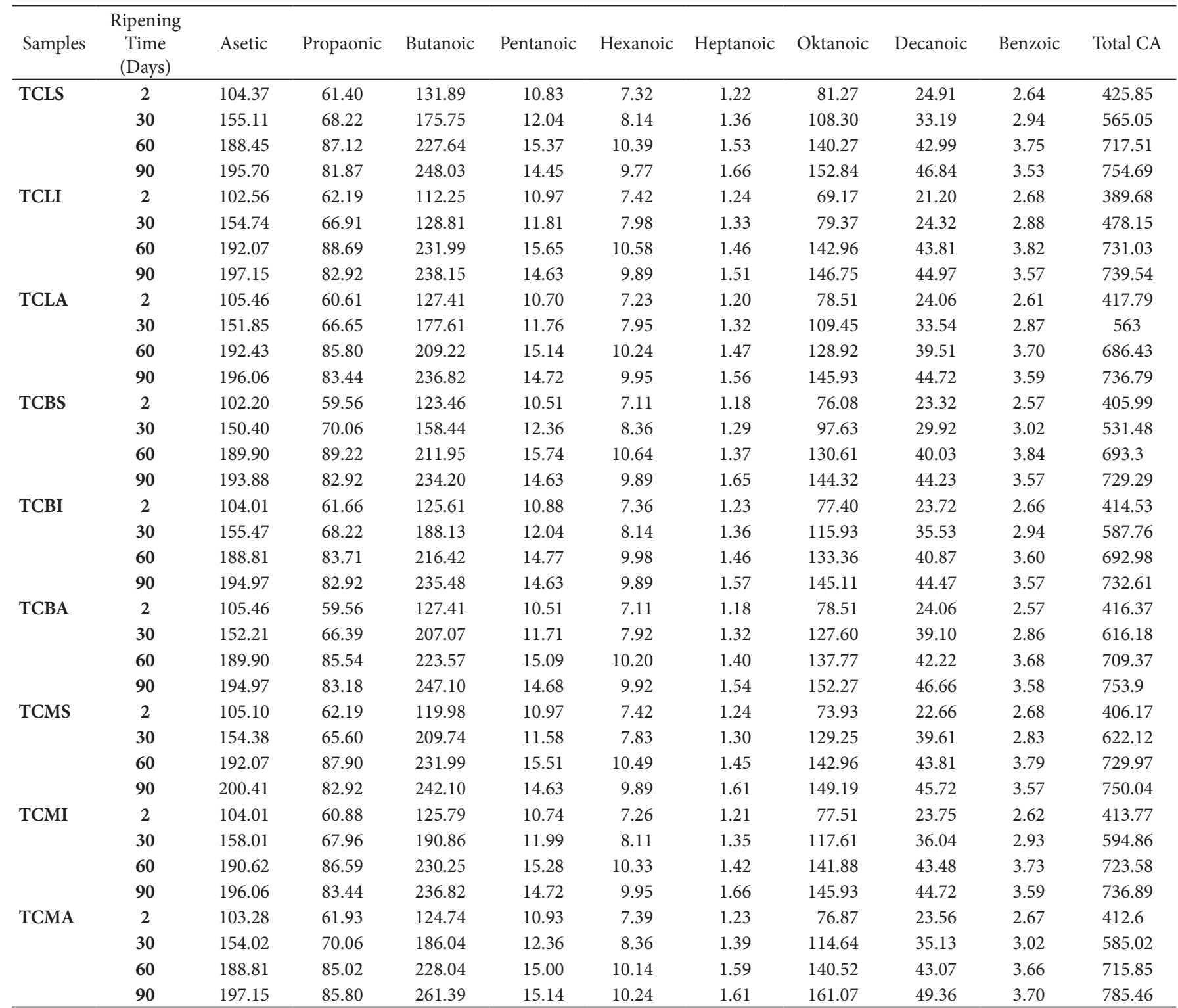

TCLS = Tulum cheese with Lactobacillus acidophilus stuffed into skin bag; TCLI = Tulum cheese with Lactobacillus acidophilus stuffed into small intestine; TCLA = Tulum cheese with Lactobacillus acidophilus stuffed into appendix; TCBS = Tulum cheese with Bifidobacterium animalis spp. lactis stuffed into skin bag; TCBI = Tulum cheese with Bifidobacterium animalis spp. lactis stuffed into small intestine; TCBA = Tulum cheese with Bifidobacterium animalis spp. lactis stuffed into appendix; TCMS = Tulum cheese with mix probiotic bacteria stuffed into skin bag; TCMI = Tulum cheese with mix probiotic bacteria stuffed into small intestine; TCMA = Tulum cheese with mix probiotic bacteria stuffed into appendix . 
Table 9. Sensory properties of Erzican Tulum cheese samples during the storage.

\begin{tabular}{|c|c|c|c|c|c|c|c|c|c|c|c|c|c|c|}
\hline \multirow{3}{*}{$\begin{array}{l}\text { Cheese } \\
\text { Samples }\end{array}$} & \multicolumn{5}{|c|}{ Appearance } & \multicolumn{4}{|c|}{ Taste and Odor } & \multicolumn{5}{|c|}{ Texture } \\
\hline & \multicolumn{5}{|c|}{ Storage Time (day) } & \multicolumn{4}{|c|}{ Storage Time (day) } & \multicolumn{5}{|c|}{ Storage Time (day) } \\
\hline & 2 & 30 & 60 & & 90 & 2 & 30 & 60 & 90 & 2 & 30 & 60 & & 90 \\
\hline TCLS & $\begin{array}{l}7.89 \pm \\
0.40^{\mathrm{Aab}}\end{array}$ & $\begin{array}{l}7.87 \pm \\
0.23^{\mathrm{Aab}}\end{array}$ & $\begin{array}{l}6.65 \pm \\
0.33^{\text {Bd }}\end{array}$ & & $\begin{array}{l}.2 \pm \\
12^{\text {Cde }}\end{array}$ & $\begin{array}{l}7.81 \pm \\
0.15^{\mathrm{Ae}}\end{array}$ & $\begin{array}{l}7.64 \pm \\
0.09^{\mathrm{Ae}}\end{array}$ & $\begin{array}{c}6.89 \pm \\
0.06^{\mathrm{Bf}}\end{array}$ & $\begin{array}{l}6.25 \pm \\
0.0 .4^{\mathrm{C}}\end{array}$ & $\begin{array}{l}8.35 \pm \\
0.10^{\mathrm{Aab}}\end{array}$ & $\begin{array}{l}8.11 \pm \\
0.08^{\mathrm{Bb}}\end{array}$ & $\begin{array}{l}7.80 \\
0.11\end{array}$ & & $\begin{array}{l}7.62 \pm \\
0.11^{\mathrm{Dc}}\end{array}$ \\
\hline TCLI & $\begin{array}{l}8.02 \pm \\
0.55^{\mathrm{ab}}\end{array}$ & $\begin{array}{l}7.94 \pm \\
0.36^{\mathrm{ab}}\end{array}$ & $\begin{array}{c}7.02 \pm \\
0.09^{c}\end{array}$ & & $\begin{array}{l}.27 \pm \\
.21^{\mathrm{d}}\end{array}$ & $\begin{array}{l}8.10 \pm \\
0.11^{\mathrm{Abc}}\end{array}$ & $\begin{array}{l}7.94 \pm \\
0.09^{\text {Acd }}\end{array}$ & $\begin{array}{l}7.43 \pm \\
0.19^{\mathrm{Bcd}}\end{array}$ & $\begin{array}{l}6.70 \pm \\
0.03^{\mathrm{Cc}}\end{array}$ & $\begin{array}{l}8.37 \pm \\
0.10^{\text {Aa }}\end{array}$ & $\begin{array}{l}8.19 \pm \\
0.06^{\mathrm{Bb}}\end{array}$ & $\begin{array}{l}7.97 \\
0.05\end{array}$ & & $\begin{array}{l}7.94 \pm \\
0.12^{\mathrm{Ca}}\end{array}$ \\
\hline TCLA & $\begin{array}{c}8.16 \pm \\
0.45^{\mathrm{a}}\end{array}$ & $\begin{array}{l}8.05 \pm \\
0.09^{\mathrm{ab}}\end{array}$ & $\begin{array}{c}7.26 \pm \\
0.10^{c}\end{array}$ & & $\begin{array}{l}.79 \pm \\
.21^{c}\end{array}$ & $\begin{array}{l}8.25 \pm \\
0.13^{\text {Aab }}\end{array}$ & $\begin{array}{l}8.05 \pm \\
0.12^{\mathrm{Abc}}\end{array}$ & $\begin{array}{l}7.49 \pm \\
0.13^{\mathrm{Bbc}}\end{array}$ & $\begin{array}{l}7.14 \pm \\
0.06^{\mathrm{Cb}}\end{array}$ & $\begin{array}{l}8.40 \pm \\
0.08^{\mathrm{Aa}}\end{array}$ & $\begin{array}{l}8.32 \pm \\
0.08^{\mathrm{Aa}}\end{array}$ & $\begin{array}{l}8.10 \\
0.07\end{array}$ & & $\begin{array}{l}7.45 \pm \\
0.10^{\mathrm{Cd}}\end{array}$ \\
\hline TCBS & $\begin{array}{l}7.91 \pm \\
0.28^{\mathrm{ab}}\end{array}$ & $\begin{array}{c}7.67 \pm \\
0.19^{\mathrm{b}}\end{array}$ & $\begin{array}{c}6.28 \pm \\
0.12^{\mathrm{e}}\end{array}$ & & $41 \pm$ & $\begin{array}{l}7.71 \pm \\
0.13^{\mathrm{Ae}}\end{array}$ & $\begin{array}{c}7.44 \pm \\
0.07^{\mathrm{Bf}}\end{array}$ & $\begin{array}{l}6.65 \pm \\
0.10^{\mathrm{Cg}}\end{array}$ & $\begin{array}{l}5.75 \pm \\
0.07^{\mathrm{D}}\end{array}$ & $\begin{array}{l}8.15 \pm \\
0.04^{\mathrm{Ac}}\end{array}$ & $\begin{array}{l}7.74 \pm \\
0.10^{\mathrm{Be}}\end{array}$ & $\begin{array}{l}7.50 \\
0.07\end{array}$ & & $\begin{array}{l}7.29 \pm \\
0.07^{\text {Dde }}\end{array}$ \\
\hline TCBI & $\begin{array}{l}8.09 \pm \\
0.15^{\mathrm{ab}}\end{array}$ & $\begin{array}{l}7.81 \pm \\
0.18^{\mathrm{ab}}\end{array}$ & $\begin{array}{l}6.56 \pm \\
0.24^{\mathrm{de}}\end{array}$ & & $84 \pm$ & $\begin{array}{l}8.02 \pm \\
0.09^{\text {Acd }}\end{array}$ & $\begin{array}{l}7.62 \pm \\
0.12^{\mathrm{Be}}\end{array}$ & $\begin{array}{l}7.26 \pm \\
0.06^{\text {Cde }}\end{array}$ & $\begin{array}{l}6.25 \pm \\
0.08^{\mathrm{D}}\end{array}$ & $\begin{array}{l}8.21 \pm \\
0.11^{\mathrm{Abc}}\end{array}$ & $\begin{array}{l}7.80 \pm \\
0.08^{\text {Bde }}\end{array}$ & $\begin{array}{l}7.59 \\
0.08\end{array}$ & & $\begin{array}{l}7.43 \pm \\
0.12^{\mathrm{Cd}}\end{array}$ \\
\hline TCBA & $\begin{array}{c}8.11 \pm \\
0.29^{\mathrm{a}}\end{array}$ & $\begin{array}{l}7.95 \pm \\
0.19^{\mathrm{ab}}\end{array}$ & $\begin{array}{c}7.15 \pm \\
0.12^{c}\end{array}$ & & $.23 \pm$ & $\begin{array}{c}8.16 \pm \\
0.07^{\mathrm{Aabc}}\end{array}$ & $\begin{array}{l}7.87 \pm \\
0.15^{\mathrm{Bcd}}\end{array}$ & $\begin{array}{c}7.34 \pm \\
0.09^{\text {Ccde }}\end{array}$ & $\begin{array}{l}6.58 \pm \\
0.10^{\mathrm{DC}}\end{array}$ & $\begin{array}{l}8.31 \pm \\
0.06^{\mathrm{Aab}}\end{array}$ & $\begin{array}{l}7.93 \pm \\
0.05^{\mathrm{Bc}}\end{array}$ & $\begin{array}{l}7.76 \\
0.03\end{array}$ & & $\begin{array}{l}7.25 \pm \\
0.05^{\mathrm{De}}\end{array}$ \\
\hline TCMS & $\begin{array}{c}7.63 \pm \\
0.26^{\mathrm{b}}\end{array}$ & $\begin{array}{c}7.73 \pm \\
0.14^{\mathrm{b}}\end{array}$ & $\begin{array}{l}7.6 \pm \\
0.12^{b}\end{array}$ & & $\begin{array}{l}93 \pm \\
.29^{\mathrm{bc}}\end{array}$ & $\begin{array}{l}7.88 \pm \\
0.08^{\text {Ade }}\end{array}$ & $\begin{array}{l}7.76 \pm \\
0.12^{\text {Ade }}\end{array}$ & $\begin{array}{c}7.19 \pm \\
0.05^{\mathrm{Be}}\end{array}$ & $\begin{array}{l}6.77 \pm \\
0.07^{\mathrm{C}}\end{array}$ & $\begin{array}{l}8.19 \pm \\
0.09^{\mathrm{Abc}}\end{array}$ & $\begin{array}{l}7.90 \pm \\
0.05^{\mathrm{Bcd}}\end{array}$ & $\begin{array}{l}7.63 \\
0.03\end{array}$ & & $\begin{array}{l}7.41 \pm \\
0.05^{\text {Dde }}\end{array}$ \\
\hline TCMI & $\begin{array}{c}8.16 \pm \\
0.20^{\mathrm{a}}\end{array}$ & $\begin{array}{l}7.94 \pm \\
0.27^{\mathrm{ab}}\end{array}$ & $\begin{array}{c}7.92 \pm \\
0.15^{\mathrm{a}}\end{array}$ & & $17 \pm$ & $\begin{array}{c}8.21 \pm \\
0.07^{\mathrm{Aabc}}\end{array}$ & $\begin{array}{l}8.22 \pm \\
0.09^{\mathrm{Ab}}\end{array}$ & $\begin{array}{l}7.67 \pm \\
0.08^{\mathrm{Bb}}\end{array}$ & $\begin{array}{l}7.25 \pm \\
0.11^{\mathrm{Cb}}\end{array}$ & $\begin{array}{c}8.30 \pm \\
0.06^{\mathrm{Aabc}}\end{array}$ & $\begin{array}{l}7.94 \pm \\
0.05^{\mathrm{Bc}}\end{array}$ & $\begin{array}{l}7.81 \\
0.08\end{array}$ & & $\begin{array}{l}7.69 \pm \\
0.11^{\mathrm{Cbc}}\end{array}$ \\
\hline TCMA & $\begin{array}{c}8.36 \pm \\
0.13^{\mathrm{a}}\end{array}$ & $\begin{array}{c}8.17 \pm \\
0.17^{\mathrm{a}}\end{array}$ & $\begin{array}{c}6.98 \pm \\
0.15^{c}\end{array}$ & & $\begin{array}{l}.75 \pm \\
.18^{\mathrm{a}}\end{array}$ & $\begin{array}{l}8.32 \pm \\
0.08^{\mathrm{ABa}}\end{array}$ & $\begin{array}{l}8.50 \pm \\
0.11^{\mathrm{Aa}}\end{array}$ & $\begin{array}{l}8.00 \pm \\
0.15^{\mathrm{BCa}}\end{array}$ & $\begin{array}{l}7.66 \pm \\
0.14^{\mathrm{C}}\end{array}$ & $\begin{array}{l}8.37 \pm \\
0.09^{\mathrm{Aa}}\end{array}$ & $\begin{array}{l}8.18 \pm \\
0.04^{\mathrm{Bb}}\end{array}$ & $\begin{array}{l}8.05 \\
0.05\end{array}$ & & $\begin{array}{l}7.80 \pm \\
0.08^{\text {Dab }}\end{array}$ \\
\hline \multirow{3}{*}{$\begin{array}{l}\text { Cheese } \\
\text { Samples }\end{array}$} & \multicolumn{7}{|c|}{ Flavor } & \multicolumn{7}{|c|}{ General Appreciation } \\
\hline & \multicolumn{7}{|c|}{ Storage Time (day) } & \multicolumn{7}{|c|}{ Storage Time (day) } \\
\hline & \multicolumn{2}{|r|}{2} & \multicolumn{2}{|l|}{30} & \multicolumn{2}{|c|}{60} & 90 & \multicolumn{2}{|c|}{2} & 30 & \multicolumn{2}{|c|}{60} & \multirow{2}{*}{\multicolumn{2}{|c|}{$5.53 \pm 0.13^{\mathrm{Ccd}}$}} \\
\hline TCLS & \multicolumn{2}{|c|}{$8.09 \pm 0.06^{\mathrm{Abcd}}$} & \multicolumn{2}{|c|}{$8.13 \pm 0.07^{\mathrm{Acd}}$} & \multicolumn{2}{|c|}{$7.53 \pm 0.12^{\mathrm{Bef}}$} & $5.7 \pm 0.05^{\mathrm{Cf}}$ & \multicolumn{2}{|c|}{$7.94 \pm 0.28^{\mathrm{Aa}}$} & $8.00 \pm 0.15^{\mathrm{Aab}}$ & \multicolumn{2}{|c|}{$7.38 \pm 0.14^{\mathrm{Bab}}$} & & \\
\hline TCLI & \multicolumn{2}{|c|}{$8.16 \pm 0.06^{\mathrm{Aabc}}$} & \multicolumn{2}{|c|}{$8.21 \pm 0.09^{\mathrm{Abcd}}$} & \multicolumn{2}{|c|}{$7.70 \pm 0.13^{\mathrm{Bcd}}$} & $5.93 \pm 0.11^{\mathrm{Ce}}$ & \multicolumn{2}{|c|}{$8.00 \pm 0.15^{\mathrm{Aa}}$} & $8.05 \pm 0.20^{\mathrm{Aab}}$ & \multicolumn{2}{|c|}{$7.52 \pm 0.44^{\mathrm{Aab}}$} & \multicolumn{2}{|c|}{$5.74 \pm 0.40^{\mathrm{Bcd}}$} \\
\hline TCLA & \multicolumn{2}{|c|}{$8.24 \pm 0.05^{\mathrm{Aa}}$} & $8.27 \pm 0.0$ & & 7.85 & $0.07^{\mathrm{Bb}}$ & $6.13 \pm 0.10^{\mathrm{Cd}}$ & $8.08=$ & $14^{\mathrm{Aa}}$ & $8.10 \pm 0.17^{\mathrm{Aab}}$ & $7.71 \pm$ & $8^{\mathrm{Aab}}$ & & $4 \pm 0.20^{\mathrm{Bc}}$ \\
\hline TCBS & 7.9 & $\pm 0.12^{\mathrm{Ad}}$ & $7.94 \pm 0.0$ & & 7.29 & $0.07^{\mathrm{Bg}}$ & $4.88 \pm 0.07^{\mathrm{C} 1}$ & $7.80=$ & $17^{\mathrm{Aa}}$ & $7.97 \pm 0.21^{\mathrm{Ab}}$ & $7.10 \pm$ & & & $2 \pm 0.17^{\mathrm{Ce}}$ \\
\hline TCBI & 8.0 & $\pm 0.09^{\mathrm{Acd}}$ & $8.08 \pm 0.1$ & & 7.48 & $0.06^{\mathrm{Bf}}$ & $5.14 \pm 0.12^{\mathrm{Ch}}$ & $7.86=$ & $30^{\mathrm{Aa}}$ & $7.88 \pm 0.14^{\mathrm{Ab}}$ & $7.24 \pm$ & & & $3 \pm 0.22^{\mathrm{Cde}}$ \\
\hline TCBA & 8.1 & $\pm 0.09^{\mathrm{Aabc}}$ & $8.18 \pm 0.0$ & & 7.66 & $0.07^{\text {Bde }}$ & $5.41 \pm 0.07^{\mathrm{Cg}}$ & $7.94=$ & $20^{\mathrm{Aa}}$ & $7.94 \pm 0.27^{\mathrm{Ab}}$ & $7.40 \pm$ & $5^{\mathrm{Aab}}$ & & $4 \pm 0.37^{\mathrm{Bcd}}$ \\
\hline TCMS & 8.1 & $\pm 0.09^{\mathrm{Aabc}}$ & $8.25 \pm 0.0$ & & 7.81 & $0.05^{\mathrm{Bbc}}$ & $6.9 \pm 0.08^{\mathrm{Cc}}$ & $8.07=$ & $16^{\mathrm{Aa}}$ & $8.14 \pm 0.19^{\mathrm{Aab}}$ & $7.61 \pm$ & $0^{\mathrm{Bab}}$ & & $3 \pm 0.28^{\mathrm{Cb}}$ \\
\hline TCMI & 8.2 & $\pm 0.07^{\mathrm{Aab}}$ & $8.33 \pm 0.0$ & & 8.06 & $0.05^{\mathrm{Ba}}$ & $7.19 \pm 0.04^{\mathrm{Cb}}$ & $8.14=$ & $14^{\mathrm{Aa}}$ & $8.22 \pm 0.21^{\mathrm{Aab}}$ & $7.95 \pm$ & & & $9 \pm 0.33^{\mathrm{Bab}}$ \\
\hline TCMA & 8.3 & $\pm 0.04^{\mathrm{Aa}}$ & $8.46 \pm 0.0$ & & 8.13 & $0.10^{\mathrm{Ba}}$ & $7.55 \pm 0.12^{\mathrm{Ca}}$ & $8.17=$ & $15^{\text {Aa }}$ & $8.36 \pm 0.15^{\mathrm{Aa}}$ & $8.03 \pm$ & $1^{\mathrm{Aa}}$ & & $4 \pm 0.25^{\mathrm{Ba}}$ \\
\hline
\end{tabular}

TCLS = Tulum cheese with Lactobacillus acidophilus stuffed into skin bag; TCLI = Tulum cheese with Lactobacillus acidophilus stuffed into small intestine; TCLA = Tulum cheese with Lactobacillus acidophilus stuffed into appendix; TCBS = Tulum cheese with Bifidobacterium animalis spp. lactis stuffed into skin bag; TCBI = Tulum cheese with Bifidobacterium animalis spp. lactis stuffed into small intestine; TCBA = Tulum cheese with Bifidobacterium animalis spp. lactis stuffed into appendix; TCMS = Tulum cheese with mix probiotic bacteria stuffed into skin bag; TCMI $=$ Tulum cheese with mix probiotic bacteria stuffed into small intestine; TCMA $=$ Tulum cheese with mix probiotic bacteria stuffed into appendix. ${ }^{\text {a-d }}(\rightarrow)$ Values with the same superscript letters in the same rows for each analysis differ significantly $(\mathrm{P}<0.05)$, a-1 $(\downarrow)$ Values with the same superscript letters in the same lines for each analysis differ significantly $(\mathrm{P}<0.05)$.

Sensory analysis results regarding the colour and appearance, taste and odour, texture, aroma and general acceptance values on the 2nd, 30th, 60th and 90th days of the storage are shown in Table 9.

Probiotic treatment affected the colour $(\mathrm{P}<0.05)$, taste and odour $(\mathrm{P}<0.01)$, texture $(\mathrm{P}<0.0001)$, flavor $(\mathrm{P}<0.05)$ and general acceptability of the Tulum cheese samples $(\mathrm{P}<0.05)$. Packaging material used in production effect colour $(\mathrm{P}<0.05)$ and taste and odour $(\mathrm{P}<0.0001)$ scores (Table 10$)$. Moreover, storage time affected all of the sensory properties of the Erzincan Tulum cheese $(\mathrm{P}<0.0001$; Table 9$)$. In general, all the sensory evaluation scores decreased during storage $(\mathrm{P}<0.05)$.

At the end of the 90-day storage period maximum decrease of colur value was detected in TCBS sample with a value of 2.50 . This value was followed by TCBI with 2.25 and TCBA with 1.88 respectively. It is thought to cause this result, the addition of $B$. animalis spp. lactis in the production of cheeses. Similarly, Tomar (2018) stated that samples containing B. animalis subsp. lactis with higher yellowness values in Tulum cheeses had lower colour scores.

During the storage period The TCMA $(\mathrm{P}>0.05)$, TCLA $(\mathrm{P}<0.05)$ samples had the highest taste and odour scores, while, TCBS and TCBI samples had the lowest taste and odor scores $(\mathrm{P}<0.05)$. The sample of containing $B$. animalis spp. lactis had a lower taste and odour score, than containing of $L$. acidophilus. Similarly, Cuffia et al. (2018) found that samples containing B. animalis spp. lactis in soft sheep's cheese had lower odour scores than L. acidophilus containing samples. In addition, the samples used in the packaging material as appendix had the highest taste and odour scores than the others $(\mathrm{P}<0.0001)$. This result is due to the differences in the reactions of lipolysis and proteolysis in the cheese samples during storage. 
Table 10. Effect of ripening time, packaging material and probiotic cultures on sensory properties of Erzican Tulum cheese samples.

\begin{tabular}{|c|c|c|c|c|c|}
\hline Source of Variation & Apparance & Taste and Odour & Texture & Flavour & $\begin{array}{c}\text { General } \\
\text { Appreciation }\end{array}$ \\
\hline \multicolumn{6}{|l|}{ Storage Time } \\
\hline 2 & $8.04 \pm 0.17^{\mathrm{a}}$ & $8.05 \pm 0.04^{\mathrm{a}}$ & $8.29 \pm 0.02^{\mathrm{a}}$ & $8.16 \pm 0.02 \mathrm{a}$ & $8.00 \pm 0.04^{\mathrm{a}}$ \\
\hline 30 & $7.90 \pm 0.41^{\mathrm{a}}$ & $7.89 \pm 0.06^{\mathrm{a}}$ & $8.01 \pm 0.04^{\mathrm{b}}$ & $8.20 \pm 0.03 a$ & $8.07 \pm 0.04^{\mathrm{a}}$ \\
\hline 60 & $7.05 \pm 0.33^{b}$ & $7.32 \pm 0.08^{\mathrm{b}}$ & $7.80 \pm 0.04^{c}$ & $7.72 \pm 0.05 b$ & $7.55 \pm 0.08^{\mathrm{b}}$ \\
\hline 90 & $6.48 \pm 0.39^{c}$ & $6.70 \pm 0.11^{\mathrm{c}}$ & $7.54 \pm 0.05^{\mathrm{d}}$ & $6.09 \pm 0.17 c$ & $5.99 \pm 0.17^{\mathrm{c}}$ \\
\hline P Value & $<0.0001$ & $<0.0001$ & $<0.0001$ & $<0.0001$ & $<0.0001$ \\
\hline \multicolumn{6}{|l|}{ Packaging Material } \\
\hline Skin Bag & $7.08 \pm 0.12^{\mathrm{b}}$ & $7.14 \pm 0.11^{\mathrm{b}}$ & $7.80 \pm 0.06^{\mathrm{b}}$ & $7.39 \pm 0.17^{\mathrm{a}}$ & $7.26 \pm 0.18^{\mathrm{a}}$ \\
\hline Intestine & $7.49 \pm 0.12^{\mathrm{ab}}$ & $7.56 \pm 0.10^{\mathrm{a}}$ & $7.94 \pm 0.05^{\mathrm{ab}}$ & $7.56 \pm 0.18^{\mathrm{a}}$ & $7.42 \pm 0.17^{\mathrm{a}}$ \\
\hline Appendix & $7.67 \pm 0.10^{\mathrm{a}}$ & $7.77 \pm 0.09^{\mathrm{a}}$ & $7.99 \pm 0.06^{\mathrm{a}}$ & $7.68 \pm 0.15^{\mathrm{a}}$ & $7.53 \pm 0.15^{\mathrm{a}}$ \\
\hline$P$ Value & 0.02 & $<0.0001$ & 0.062 & 0.453 & 0.488 \\
\hline \multicolumn{6}{|l|}{ Probiotic Culture } \\
\hline Lactobacillus acidophilus & $7.22 \pm 0.12^{\mathrm{b}}$ & $7.47 \pm 0.10^{\mathrm{b}}$ & $8.05 \pm 0.05^{\mathrm{a}}$ & $7.49 \pm 0.16^{\mathrm{b}}$ & $7.33 \pm 0.16^{\mathrm{b}}$ \\
\hline Bifidobacterium animalis spp. lactis & $7.21 \pm 0.14^{\mathrm{b}}$ & $7.22 \pm 0.12^{\mathrm{b}}$ & $7.74 \pm 0.06^{\mathrm{b}}$ & $7.19 \pm 0.21^{\mathrm{b}}$ & $7.06 \pm 0.19^{\mathrm{b}}$ \\
\hline MIX & $7.75 \pm 0.74^{\mathrm{a}}$ & $7.79 \pm 0.08^{\mathrm{a}}$ & $7.94 \pm 0.05^{\mathrm{a}}$ & $7.95 \pm 0.08^{\mathrm{a}}$ & $7.82 \pm 0.10^{\mathrm{a}}$ \\
\hline P Value & 0.03 & 0.001 & $<0.0001$ & 0.04 & 0.03 \\
\hline
\end{tabular}

Values with the same superscript letters in the same column for each analysis differ significantly $(\mathrm{P}<0.05)$.

The difference of probiotic bacteria used in cheese production were effective on textur socores $(\mathrm{P}<0.0001)$. Samples with contanining $L$. acidophilus had the highest score while samples containing $B$. animalis spp. lactis had the lowest score during the storage $(\mathrm{P}<0.05)$. On the other hand, the difference of packaging material were not effective on textur socores $(\mathrm{P}>0.05$; Table 10$)$.

The flavour in dairy products is mainly attributed to the high content of shortand medium-chain fatty acids (Prandini et al., 2011; Raynal- Ljutovac et al., 2011). The flavour scores of the Tulum samples decreased during storage $(\mathrm{P}<0.05)$. The probiotic culture effect flavour scores of Erzincan Tulum cheese $(\mathrm{P}<0.05)$.

Samples containing mixed culture (TCMS, TCMI and TCMA) had the highest scores, while samples containing $B$. animalis spp. lactis (TCBS, TCBI and TCBA) had the lowest flavour scores. Like with texture scores, packaging difference were not effect on flavour scores $(\mathrm{P}>0.05)$.

The probiotic culture affects general acceptance values cheese samples $(\mathrm{P}<0.05)$. According to the general acceptance values, the most favoured sample was TCMA with $7.34 \pm 0.25$ score (containing mix culture), whereas the least favoured was TCBS with $4.82 \pm 0.17$ score (containing B. animalis spp. lactis) $(\mathrm{P}<0.05)$. Unlike the use of different packaging in cheese production had not effective on the general acceptance values $(\mathrm{P}>0.05)$.

These results show that adding L. acidophilus and MIX cultures did not produce defects in sensory scores and could even improve the organoleptic characteristics of Erzincan Tulum cheese. Similarly, Minervini et al. (2012), Cuffia et al. (2018) and Tomar (2018) reported that the addition of probiotic strains improved the sensory properties of cheese during the ripening.

According to these results, Tulum cheese is a suitable food matrix for probiotic bacteria. Similarly, various researchers have stated that cheese is a well-established food matrix for probiotic bacteria due to its intrinsic nutritional composition (Lollo et al.,
2015; Thomas, 2016; Champagne et al., 2018; Almeida et al., 2018a; Tomar, 2018).

\section{Conclusion}

Today, the tendency to consume organic and healthy foods in the world is increasing.

Studies have shown that healthy diet, is the key to be healthy, physically and mentally. Therefore, regular and adequate probiotic consumption in daily nutrition is extremely important. Our study demonstrates the efficacy of using a probiotic culture to improve the overall acceptability of Tulum cheese, which is very significant as far as human health is concerned.

Tulum cheese is a type of cheese that has an important place among the Turkish cheeses and is consumed abundantly and admirably. Adding probiotic bacteria to this cheese during its production impacts physicochemical, chemical and physical characteristics of the cheese positively and at the same time, aroma components that occur during the ripening depending on lipolysis and proteolysis also impact positively on the quality growth of the cheese. In addition to these, adding probiotic bacteria during the production gained significant functionality to the cheese that has beneficial effects on human health, particularly the digestive system.

The fact that the Tulum cheese has a place in dairy products, in which probiotic bacteria are added the most, will give a new meaning and importance to this cheese, which is consumed admirably and abundantly. Also, loss of sensory and visual taste that are caused by the Tulum that is the traditional packaging of the Tulum cheese, was replaced by using different packaging materials during the production. The taste and aroma of the product were enhanced to produce a more appealing product with aesthetic and health benefits for the food industry in both Turkey and the World. 


\section{References}

Akpınar, A., Yerlikaya, O., Kinik, Ö., Korel, F., Kahraman, C., \& Uysal, H. R. (2017). Some physicochemical characteristics and aroma compounds of izmir tulum cheese produced with different milk types. Ege Journal of Agricultural Research, 54(1), 27-35.

Almeida, J. S. O., Dias, C. O., Pinto, S. S., Pereira, L. C., Verruck, S., Fritzen-Freire, C. B., \& Amboni, R. D. (2018a). Probiotic Mascarponetype cheese: Characterisation and cell viability during storage and simulated gastrointestinal conditions. International Journal of Dairy Technology, 71, 195-203. http://dx.doi.org/10.1111/1471-0307.12457.

Almeida, J. S. O., Dias, C. O., Pinto, S. S., Pereira, L. C., Verruck, S., Fritzen-Freire, C. B., Amante, E. R., Prudêncio, E. S., \& Amboni, R. D. M. C. (2018b). Probiotic Mascarpone-type cheese: characterisation and cell viability during storage and simulated gastrointestinal conditions. International Journal of Dairy Technology, 71, 195-203. http://dx.doi.org/10.1111/1471-0307.12457.

Alves, L. L., Richards, N. S. P. S., Mattanna, P., Andrade, D. F., Milani, L. I. G., Cruz, G. A., \& Faria, J. A. F. (2013). Cream cheese as a symbiotic food carrier using Bifidobacterium animalis $\mathrm{Bb}-12$ and Lactobacillus acidophilus La-5 and inulin. International Journal of Dairy Technology, 66(1), 63-69. http://dx.doi.org/10.1111/j.14710307.2012.00880.x.

Association of Official Analytical Chemists - AOAC. (2012). AOAC official method 937.05 lactic acid in milk and milk products (19th ed.). Washington: AOAC.

Attaie, R., \& Richter, R. L. (1996). Formation of Volatile free fatty acidsduring ripening of Cheddar-like goat cheese. Journal of Dairy Science, 79(5), 717-724. http://dx.doi.org/10.3168/jds.S00220302(96)76418-4.

Banks, J. M., Yvon, M., Gripon, J. C., de la Fuente, A., Brechany, E. Y., Williams, A. G., \& Muir, D. D. (2001). Enhancement of amino acid catabolism in Cheddar cheese using a-ketoglutarate: amino acid degradation in relation to volatile compounds and aroma character. International Dairy Journal, 11(4), 235-243. http://dx.doi. org/10.1016/S0958-6946(01)00053-X.

Barron, L., Redondo, Y., Aramburu, M., Pérez-Elortondo, F. J., Albisu, M., Nájera, A. I., \& Renobales, M. (2005). Variations in Volatile compounds and flavour in idiazabal cheese manufactured from ewe's milk in farmhouse and factory. Journal of the Science of Food and Agriculture, 85(10), 1660-1671. http://dx.doi.org/10.1002/jsfa.2175.

Buffa, M., Guamis, B., Pavia, M., \& Trujillo, A. J. (2001). Lipolysis in cheese madefrom raw, pasteurized or high pressure treated goats' milk. International Dairy Journal, 11(3), 175-179. http://dx.doi. org/10.1016/S0958-6946(01)00044-9.

Çakır, Y., \& Cakmakci, S. (2018). Some microbiological, physicochemical and ripening properties of Erzincan Tulum cheese produced with added black cumin (Nigella Sativa L.). Journal of Food Science and Technology, 55(4), 1435-1443. http://dx.doi.org/10.1007/s13197018-3058-5. PMid:29606758.

Cakir, Y., Cakmakci, S., \& Hayaloglu, A. A. (2016). The effect of addition of black cumin (Nigella sativa L.) and ripening period on proteolysis, sensory properties and volatile profiles of Erzincan Tulum (Savak) cheese made from raw Akkaraman sheep's milk. Small Ruminant Research, 134, 65-73. http://dx.doi.org/10.1016/j. smallrumres.2015.12.004.

Cakmakci, S., Dagdemir, E., Hayaloglu, A. A., Gurses, M., Cetin, B., \& Tahmas Kahyaoglu, D. (2013). Effect of Penicillium roqueforti and incorporations of whey cheese on volatile profiles and sensory characteristics of mould-ripened Civil cheese. International Journal of Dairy Technology, 66, 512-526. http://dx.doi.org/10.1111/14710307.12069.

Celik, F. O., \& Tarakci, Z. (2017). The effects of starter cultures on chemical, biochemical and sensory properties of low-fat Tulum cheeses during ripening. International Journal of Dairy Technology, 47(4), 583-591. http://dx.doi.org/10.1111/1471-0307.12377.

Champagne, C. P., Cruz, A. G., \& Daga, M. (2018). Strategies to improve the functionality of probiotics in supplements and foods. Current Opinion in Food Science, 22, 160-166. http://dx.doi.org/10.1016/j. cofs.2018.04.008.

Champagne, C. P., Gardner, N. J., \& Roy, D. (2005). Challenges in the addition of probiotic cultures to foods. Critical Reviews in Food Science and Nutrition, 45(1), 61-84. http://dx.doi.org/10.1080/10408690590900144. PMid:15730189.

Collins, Y. F., McSweeney, P. L. H., \& Wilkinson, M. (2003). Lipolysis and free fatty acid catabolism in cheese: a review of current knowledge. International Dairy Journal, 13(11), 841-866. http:// dx.doi.org/10.1016/S0958-6946(03)00109-2.

Cruz, A. G., Alonso Buriti, F. C., Batista de Souza, C. H., Fonseca Faria, J. A., \& Isay Saad, S. M. (2009). Probiotic cheese: health benefits, technological and stability aspects. Trends in Food Science \& Technology, 20(8), 344-354. http://dx.doi.org/10.1016/j.tifs.2009.05.001.

Cruz, A. G., Faria, J. A. F., \& Van Dender, A. G. F. (2007). Packaging system and probiotic dairy foods. Food Research International, 40(8), 951-956. http://dx.doi.org/10.1016/j.foodres.2007.05.003.

Cuffia, F., Bergamini, C., \& Candioti, M. (2018). Probiotic soft sheep's cheese: evaluation of probiotic survival and its influence on proteolysis and organoleptic characteristics. International Food Research Journal, 25, 399-407.

Curioni, P. M. G., \& Bosset, J. O. (2002). Key odorants in various cheese types as determined by gas chromatography-olfactometry. International Dairy Journal, 12(12), 959-984. http://dx.doi.org/10.1016/ S0958-6946(02)00124-3.

Dagdemir, E. (2006). Identification of lactic acid bacteria isolated from White Pickled Cheeses and possibilities of using some selected isolats as culture (Ph.D. thesis). Graduate School of Natural and Applied Science, Atatürk University, Erzurum, Turkey.

Dunn, H. C., \& Lindsay, R. C. (1985). Evaluation of the role of microbial strecker-derivated aroma compounds in unclean-type flavours of Cheddar cheese. Journal of Dairy Science, 68(11), 2859-2874. http:// dx.doi.org/10.3168/jds.S0022-0302(85)81179-6.

Ercan, D., Korel, F., Yüceer, Y. K., \& Kınık, O. (2011). Physicochemical, textural, volatile, and sensory profiles of traditional Sepet cheese. Journal of Dairy Science, 94(9), 4300-4312. http://dx.doi.org/10.3168/ jds.2010-3941. PMid:21854903.

Gun, I. (2012). Effects of alternative casing materials on quality properties of Tulum cheese (Ph.D. thesis). Graduate School of Natural and Applied Science, Suleyma Demirel University, Isparta, Turkey.

Hayaloglu, A. A. (2009). Volatile composition and proteolysis in traditionally produced mature Kashar cheese. International Journal of Food Science \& Technology, 44(7), 1388-1394. http://dx.doi. org/10.1111/j.1365-2621.2009.01968.x.

Hayaloglu, A. A., \& Brechany, E. Y. (2007). Influence of milk pasteurization and scalding temperature on the volatile compounds of Malatya, a farm house Halloumi type cheese. Le Lait, 87(1), 39-57. http:// dx.doi.org/10.1051/lait:2006025.

Hayaloglu, A. A., \& Karabulut, I. (2013). SPME/GC-MS characterization and comparison of volatiles of eleven varieties of Turkish cheeses. International Journal of Food Properties, 16(7), 1630-1653. http:// dx.doi.org/10.1080/10942912.2011.587625. 
Hayaloglu, A. A., Brechany, E. Y., Deegan, K. C., \& McSweeney, P. L. H. (2008). Characterization of chemistry, biochemistry and volatile profiles of Kuflu cheese, a mould-ripened variety. LebensmittelWissenschaft + Technologie, 41(7), 1323-1334. http://dx.doi. org/10.1016/j.lwt.2007.08.020.

Hayaloglu, A. A., Cakmakci, S., Brechany, E. Y., Deegan, K. C., \& McSweeney, P. L. H. (2007). Microbiology, biochemistry and volatile composition of Tulum cheese ripened in goat's skin or plastic bags. Journal of Dairy Science, 90(3), 1102-1121. http://dx.doi.org/10.3168/ jds.S0022-0302(07)71597-7. PMid:17297085.

Hill, C., Guarner, F., Reid, G., Gibson, G. R., Merenstein, D. J., Pot, B., Morelli, L., Canani, R. B., Flint, H. J., Salminen, S., Calder, P. C., \& Sanders, M. E. (2014). Expert consensus document: the international scientific association for probiotics and prebiotics consensus statement on the scope and appropriate use of the term probiotic. Nature Reviews. Gastroenterology \& Hepatology, 11(8), 506-514. http://dx.doi.org/10.1038/nrgastro.2014.66. PMid:24912386.

Holland, R., Liu, S. Q., Crow, V. L., Delabre, M. L., Lubbers, M., Bennett, M., \& Norris, G. (2005). Esterases of lactic acid bacteria and cheese flavour: Milk fat hydrolysis, alcoholysis and esterification. International Dairy Journal, 15(6-9), 711-718. http://dx.doi.org/10.1016/j. idairyj.2004.09.012.

Kamaly, K. M., Takayama, K., \& Marth, E. H. (1990). Acylglycerol acylhydrolase (lipase) activities of Streptococcus lactis, Streptococcus cremoris and their mutants. Journal of Dairy Science, 73(2), 280-290. http://dx.doi.org/10.3168/jds.S0022-0302(90)78671-7.

Kinik, O., Kesenkas, H., Ergonul Gunc, P., \& Akan, E. (2017). The effect of using pro and prebiotics on the aromatic compounds textural and sensorial properties of symbiotic goat cheese. Mljekarstvo, 67(1), 71-85.

Kurt, A., Cakmakci, S., \& Caglar, A. (2015). Milk and dairy products examination and analysis methods guide (10th ed., Publication, No. 18, Course Books Series, No. 252). Erzurum: Faculty of Agriculture, Ataturk University.

Lavasani, R. S., \& Ehsani, M. R. (2012). Effect of Bifidobacterium lactis on free fatty acids of Lighvan cheese during ripening. Journal of Medical and Bioengineering, 1(1), 4-6. http://dx.doi.org/10.12720/ jomb.1.1.4-6.

Liu, S. Q., Holland, R., \& Crow, V. L. (2004). Esters and their biosynthesis in fermented dairy products: a review. International Dairy Journal, 14(11), 923-945. http://dx.doi.org/10.1016/j.idairyj.2004.02.010.

Lollo, P. C. B., Morato, P. N., Moura, C. S., Almada, C. N., Felicio, T. L., Esmerino, E. A., Barros, M. E., Amaya-Farfan, J., Sant'Ana, A. S., Raices, R. R. S., Silva, M. C., \& Cruz, A. G. (2015). Hypertension parameters are attenuated by the continuous consumption of probiotic Minas cheese. Food Research International, 76(Pt 3), 611-617. http:// dx.doi.org/10.1016/j.foodres.2015.07.015. PMid:28455044.

Mallia, S., Fernandez-García, E., \& Bosset, J. O. (2005). Comparison of purge and trap and solid phase microextraction techniques for studying the volatile aroma compounds of three european pdo hard cheeses. International Dairy Journal, 15(6-9), 741-758. http://dx.doi. org/10.1016/j.idairyj.2004.11.007.

McSweeney, P. L. H., \& Sousa, M. J. (2000). Biochemical pathways for the production of flavour compounds in cheeses during ripening: a review. Le Lait, 80(3), 293-324. http://dx.doi.org/10.1051/lait:2000127.

Minervini, F., Siragusa, S., Faccia, M., Dal Bello, F., Gobbetti, M., \& De Angelis, M. (2012). Manufacture of Fior di Latte cheese by incorporation of probiotic lactobacilli. Journal of Dairy Science, 95(2), 508-520. http://dx.doi.org/10.3168/jds.2011-4150. PMid:22281315.

Molimard, P., \& Spinnler, H. E. (1996). Compounds involved in the flavour of surface mold-ripened cheeses: origins and properties.
Journal of Dairy Science, 79(2), 169-184. http://dx.doi.org/10.3168/ jds.S0022-0302(96)76348-8.

Mukdsi, M. C. A., Haro, C., Gonzalez, S. N., \& Medina, R. B. (2013). Functional goat milk cheese with feruloyl esterase activity. Journal of Functional Foods, 5(2), 801-809. http://dx.doi.org/10.1016/j. jff.2013.01.026.

Murtaza, M. A., Huma, N., Shabbir, M. A., Murtaza, M. S., \& Anees Ur Rehman, M. (2017). Survival of micro-organisms and organic acid profile of probiotic Cheddar cheese from buffalo milk during accelerated ripening. International Journal of Dairy Technology, 70(4), 562-571. http://dx.doi.org/10.1111/1471-0307.12406.

Nogueira, M. C. L., Lubachevsky, G., \& Rankin, S. A. (2005). A study of the volatile composition of Minas cheese. Lebensmittel-Wissenschaft + Technologie, 38(5), 555-563. http://dx.doi.org/10.1016/j.lwt.2004.07.019.

Ortigosa, M., Arizcun, C., Torre, P., \& Izco, J. M. (2005). Use of wild Lactobacillus strains in an adjunct culture for a Roncal-type cheese. The Journal of Dairy Research, 72(2), 168-178. http://dx.doi. org/10.1017/S002202990400069X. PMid:15909682.

Prandini, A., Sigolo, S., \& Piva, G. (2011). A comparative study of fatty acid composition and CLA concentration in commercial cheeses. Journal of Food Composition and Analysis, 24(1), 55-61. http://dx.doi. org/10.1016/j.jfca.2010.04.004.

Qian, M., \& Reineccius, G. (2002). Identification of aroma compounds in Parmigiano-Reggiano cheese by gas chromatography/olfactometry. Journal of Dairy Science, 85(6), 1362-1369. http://dx.doi.org/10.3168/ jds.S0022-0302(02)74202-1. PMid:12146465.

Raynal-Ljutovac, K., Le Pape, M., Gaborit, P., \& Barrucand, P. (2011). French goat milk cheeses: an overview on their nutritional and sensorial characteristics and their impacts on consumers' acceptance. Small Ruminant Research, 101(1-3), 64-72. http://dx.doi.org/10.1016/j. smallrumres.2011.09.026.

Sengul, M., Erkaya, T., Dervisoglu, M., Aydemir, O., \& Gul, O. (2014). Compositional, biochemical and textural changes during ripening of Tulum cheese made with different coagulants. International Journal of Dairy Technology, 67(3), 373-383. http://dx.doi.org/10.1111/14710307.12120.

Sert, D., Akin, N., \& Aktumsek, A. (2014). Lipolysis in Tulum Cheese produced from raw and pasteurized goats' milk during ripening. Small Ruminant Research, 121(2-3), 351-360. http://dx.doi.org/10.1016/j. smallrumres.2014.06.006.

Silva, H. L. A., Balthazar, C. F., Esmerino, E. A., Cucinelli, R. P., No., Rocha, R. S., Moraes, J., Cavalcanti, R. N., Franco, R. M., Tavares, M. I. B., Santos, J. S., Granato, D., Costa, R. G. B., Freitas, M. Q., Silva, M. C., Raices, R. S. L., Senaka Ranadheera, C., Nazzaro, F., Mortazavian, A. M., \& Cruz, A. G. (2018a). Partial substitution of $\mathrm{NaCl}$ by $\mathrm{KCl}$ and addition of flavor enhancers on probiotic Prato cheese: a study covering manufacturing, ripening and storage time. Food Chemistry, 248, 192-200. http://dx.doi.org/10.1016/j. foodchem.2017.12.064. PMid:29329843.

Silva, H. L. A., Balthazar, C. F., Rocha, R. S., Moraes, J., Esmerino, E. A., Silva, M. C., Raices, R. S. L., Pimentel, T. C., Freitas, M. Q., \& Cruz, A. G. (2018b). Sodium reduction and flavor enhancers addition: is there an impact on the availability of minerals from probiotic Prato cheese? LWT, 93, 287-292. http://dx.doi.org/10.1016/j.lwt.2018.03.053.

Stanton, C., Gardiner, G., Lynch, P. B., Collins, J. K., Fitzgerald, G., \& Ross, R. P. (1998). Probiotic cheese. International Dairy Journal, 8(5-6), 491-496. http://dx.doi.org/10.1016/S0958-6946(98)00080-6.

Talwalkar, A., \& Kallasapathy, K. (2003). A review of oxygen toxicity in probiotic yogurts: influence on the survival of probiotic bacteria and protective techniques. Science and Food Safety, 3, 117-124. 
Tarakci, Z., \& Durmuş, Y. (2016). Effects of packaging materials on some ripening characteristics of Tulum cheese. Mljekarstvo, 66, 293-303. http://dx.doi.org/10.15567/mljekarstvo.2016.0405.

Thomas, L. V. (2016). Probiotics: the journey continues. International Journal of Dairy Technology, 69(4), 469-480. http://dx.doi. org/10.1111/1471-0307.12354.

Tomar, O. (2018). The effects of probiotic cultures on the organic acid content, texture profile and sensory attributes of Tulum cheese. Journal of Dairy Technology, 70, 1-11. http://dx.doi.org/10.1111/14710307.12574.

Tomar, O., Akarca, G., Beykaya, M., \& Caglar, A. (2018). Some characteristics of Erzincan Tulum cheese produced using different probiotic cultures and packaging material. Journal of the Faculty of Veterinary Medicine, 24, 647-654.

Urbach, G. (1997). The chemical and biochemical basis of cheese and milk aroma. In B. A. Law (Ed.), Microbiology and biochemistry of cheese and fermented milk (2nd ed., pp. 253-298). London: Blackie
Academic and Professional. http://dx.doi.org/10.1007/978-1-46131121-8_8.

Wolf, I. V., Perotti, M. C., \& Zalazar, C. A. (2011). Composition and volatile profiles of commercial Argentinean Blue cheese. Journal of the Science of Food and Agriculture, 91(2), 385-393. http://dx.doi. org/10.1002/jsfa.4198. PMid:20981732.

Yasar, K. (2007). Effects of different coagulants used and ripening period on properties of Kashar cheese (Ph.D. thesis). Graduate School of Natural and Applied Science, Çukurova University, Adana, Turkey.

Yilmaz, G., Ayar, A., \& Akin, N. (2005). The effect of microbial lipase on the lipolysis during the ripening of Tulum cheese. Journal of Food Engineering, 69(3), 269-274. http://dx.doi.org/10.1016/j. jfoodeng.2004.08.017.

Zengin, G., Cakmak, Y. S., Guler, G. O., Oguz, E., Aktumsek, A., \& Akin, M. (2011). The effect of pasteurisation temperature on the CLA content and fatty acid composition of White Pickled cheese. International Journal of Dairy Technology, 64(4), 50. http://dx.doi. org/10.1111/j.1471-0307.2011.00697.x. 